\title{
Duygusal Tanıma Belleğinin Sağlamlaşma ve Kodlama Așamaları Temelinde İncelenmesi
}

\section{Evaluation of Emotional Recognition Memory in the Scope of Consolidation and Encoding Processes}

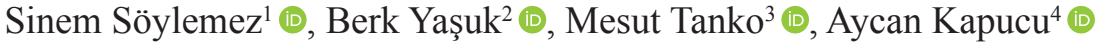

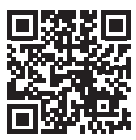

Yazar notu: Deneylere katılım sağlayarak destek veren tüm öğrencilerimize teşekkür ederiz.

${ }^{1}$ Ar. Gör., Manisa Celal Bayar Üniversitesi, Psikoloji Bölümü, Fen-Edebiyat Fakültesi, Manisa, Türkiye

${ }^{2}$ Yüksek Lisans Öğrencisi, İzmir Katip Çelebi Üniversitesi, Sosyal Bilimler Enstitüsü, Psikoloji Bölümü, İzmir, Türkiye ${ }^{3}$ Yüksek Lisans Öğrencisi, The University of Sheffield, Faculty of Science, MSc Cognitive and Computational Neuroscience, Department of Psychology, Sheffield, United Kingdom ${ }^{4}$ Doçent Dr., Ege Üniversitesi, Psikoloji Bölümü, Edebiyat Fakültesi, İzmir, Türkiye

ORCID: S.S. 0000-0002-3785-9340;

B.Y. 0000-0002-1613-8755;

M.T. 0000-0002-2966-3196;

A.K. 0000-0001-7340-9876

Sorumlu yazar/Corresponding author: Sinem Söylemez,

Manisa Celal Bayar Üniversitesi, Psikoloji Bölümü, Fen-Edebiyat Fakültesi Muradiye Kampüsü, Manisa, Türkiye

E-posta/E-mail:

sinem.nokta@gmail.com

Başvuru/Submitted: 20.08.2020

Kabul/Accepted: 01.11.2020

Online Yayın/Published Online: 10.03.2021

Citation/Atıf: Soylemez, S., Yasuk, B., Tanko, M. \& Kapucu, A. (2021). Duygusal tanıma belleğinin sağlamlaşma ve kodlama aşamaları temelinde incelenmesi. Psikoloji Çalışmaları - Studies in Psychology, 41(1): 247-278.

https://doi.org/10.26650/SP2020-0125
ÖZ

Duygusal ve nötr uyaranlar tanıma belleği bakımından farklılaşabilmektedir. Sağlamlaşma ve kodlama süreçlerine odaklanan çalışmalar söz konusu farklılaşmaya ilişkin çeşitli açıklamalar getirmiştir. Bu çalışmada, tanıma belleğinin duygusal ve nötr uyaranlar için ne şekilde farklılaştığını söz konusu açıklamalar doğrultusunda incelemek üzere iki ayrı deney yapılmıştır. Birinci deneyde zaman aralığının ve karıştırıcı görevin etkisi incelenmiştir; sağlamlaşma çalışmaları hem zaman aralığının hem de engelleme görevinin duygusal uyaranlara, nötr uyaranlara kıyasla bellek avantajı sağladığını göstermektedir. İkinci deneyde ise sunum şeklinin (tekli veya karışık) ve semantik ilişkiselliğin etkileri test edilmiştir; bu değişkenlerin kodlama aşamasında etkili olduğu öne sürülmektedir. Birinci deneye 120, ikinci deneye 60 kişi katılmış; katılımcıların tanıma belleği performansı sinyal tespit analizi ile değerlendirilmiştir. Birinci deney zaman aralığı ve karıştırıcı görevin duygusal tanıma belleği üzerinde anlamlı bir etkisinin olmadığını göstermiştir. Bununla birlikte duygunun anlamlı bir etkisi bulunmuş ve katılımcıların nötr kelimelere kıyasla duygusal kelimelere yönelik olarak liberal tepki yanlılığı gösterdiği, bu kelimeleri daha kötü tanıdıkları görülmüştür. İkinci deney ise semantik ilişkisellik ve liste türünün duygusal bellek üzerinde anlamlı bir etkisinin olmadığını göstermiştir. Öte yandan birinci deneyle tutarlı olarak duygunun anlamlı bir etkiye sahip olduğu bulunmuştur. Duygusal kelimelere yönelik olarak liberal tepki yanlılığ gösterildiği ve bu kelimelerin nötr olanlara kıyasla daha kötü tanındığı bulgusu yinelenmiştir. Sonuç olarak, sinyal tespit analizi ile değerlendirilen bu iki deneyde sağlamlaşma ve kodlama aşamasında etkili olması beklenen değişkenlerin tanıma belleğini etkilemediği gösterilmiştir. Bununla birlikte her iki deneyde de duygunun düşük tanıma doğruluğu ve yüksek liberal tepki yanlılığına neden olması, duygunun bellekteki işlevinin doğruluktan ziyade liberal tepki yanlılığ sağlamak olabileceğine işaret etmektedir.

Anahtar Kelimeler: Duygusal bellek, sağlamlaşma, kodlama, sinyal tespit analizi 


\section{ABSTRACT}

Emotional and neutral stimuli may differ in recognition memory. Research focusing on consolidation and encoding processes has offered several explanations of this differentiation. In this study, two experiments were conducted to test how recognition memory differs from emotional and neutral stimuli in the light of these explanations. In Experiment 1 , the effects of different retention intervals and an interference task were tested. Consolidation studies claim that both retention intervals and interference tasks provide memory advantages for emotional stimuli compared to neutral stimuli. In Experiment 2, the effects of presentation style (pure or mixed lists) and semantic relatedness were tested and were suggested as effective during the encoding process. Experiment 1 included 120 student participants and 60 students participated in Experiment 2. Participants' recognition memory performance was measured using signal detection analysis. Data from Experiment 1 indicated that neither the retention interval nor the interference task had significant effects on emotional recognition memory. However, emotion had a significant effect because participants presented a more liberal response bias toward emotional than neutral words and demonstrated a poorer recognition of these words than the neutral ones. Experiment 2 indicated that neither the presentation style nor semantic relatedness had significant effects on emotional recognition memory. On the other hand, emotion had a significant effect consistent with the first experiment. The liberal response bias shift and poorer recognition accuracy of emotional compared to neutral words were replicated. As a result, these two experiments using signal detection analysis demonstrated that the variables expected to be effective during the consolidation and encoding processes did not affect emotional recognition memory. However, the finding that emotion causes poorer recognition accuracy and higher liberal response bias in both experiments suggests that the function of emotion in memory may be the provision of liberal response bias rather than accuracy.

Keywords: Emotional memory, consolidation, encoding, signal detection analysis

\section{EXTENDED ABSTRACT}

It is widely accepted that emotional stimuli are remembered more easily than neutral ones. The present study tested how recognition memory of emotional stimuli differs from neutral stimuli during consolidation and encoding processes. Two experiments were conducted in the current study.

Consolidation studies claim that emotional information becomes stronger in memory as time passes (Dudai, 2004; McGaugh, 2018) and is more resistant to interference than neutral information (Cocenas-Silva, Bueno, \& Droit-Volet, 2013). Experiment 1 (E1) tested the effects of different retention intervals and the presence or absence of an interference task on the consolidation of emotional vs. neutral words using a recognition memory paradigm. We predicted that emotional stimuli would be recognized more easily than neutral ones during longer retention intervals and when an interference task was present.

Encoding studies suggest that other cognitive factors during the encoding phase might affect emotional memory (Talmi, Luk, McGarry, \& Moscovitch, 2007). Previous research has suggested that when emotional and neutral stimuli are presented in a mixed list during encoding, the emotional value might carry over to the neutral stimuli (carryover effect, Schmidt \& Schmidt, 2016). Moreover, previous research has shown that emotional words have a higher semantic interrelatedness than neutral words which might cause a more liberal 
response bias (Buchanan, Etzel, Adolphs, \& Tranel, 2006; White, Kapucu, Bruno, Rotello, \& Ratcliff, 2014). Therefore, the possible effects of presentation style and semantic relatedness on emotional recognition memory were tested in Experiment 2 (E2). We expected that the recognition accuracy of neutral words would decrease in pure lists and the liberal bias toward highly-arousing negative words would decrease when their semantic relatedness was matched with neutral words.

\section{Method}

A hundred and twenty students (27 males) participated in E1. Participants first studied 30 highly-arousing negative and 30 neutral words. Immediately after encoding, half the participants were given an interference task, while the other half were not. The retention interval was also manipulated between-subjects: 10 minutes, 30 minutes, or 60 minutes. Recognition tests included 60 previously-studied words mixed with 60 new words (30 highly-arousing negative, 30 neutral).

Sixty students ( 5 males) participated in E2. Participants were randomly assigned to conditions. A pilot study was conducted with 100 participants to determine the semantic relatedness value of each word. Next, four different study lists were created by manipulating the presentation style (pure or mixed lists) and semantic relatedness (same or different for emotional and neutral words). Participants randomly studied one of the lists and were given a recognition test 10 minutes after the encoding phase.

\section{Results}

Signal detection analysis (Macmillan \& Creelman, 2005) was used to estimate recognition accuracy ( $A U C$-area under the ROC curve) and response bias (c).

For E1, mixed design ANOVA results indicated that word type (emotional or neutral) had a significant effect on both the hit $\left(F(1,114)=109.71, p<.001, \eta_{p}^{2}=.49\right)$ and the false alarm rates $\left(F(1,114)=287.24, p<.001, \eta_{p}^{2}=.72\right)$. Also, word type had a significant effect on both memory accuracy $\left(F(1,114)=23.91, p<.001, \eta_{p}^{2}=.17\right)$ and response bias $(F(1,114)=$ $\left.320.82, p<.001, \eta_{p}{ }^{2}=.74\right)$. On the other hand, neither retention interval, nor the interference task had a significant effect on recognition memory measures.

For E2, mixed designs ANOVA indicated that word type had a significant effect on both hit $\left(F(1,76)=20.20, p<.001, \eta_{p}^{2}=.21\right)$ and false alarm rates $(F(1,76)=199.96, p<.001$, $\left.\eta_{p}{ }^{2}=.73\right)$. In addition, word type had a significant effect on both memory accuracy $(F(1,76)$ $\left.=34.94, p<.001, \eta_{p}{ }^{2}=.32\right)$ and response bias $\left(F(1,76)=33.32, p<.001, \eta_{p}{ }^{2}=.64\right)$. Emotional 
words were more poorly recognized and responded to more liberally than the neutral words. On the other hand, neither presentation style, nor semantic relatedness had a significant effect on recognition memory measures.

\section{Discussion}

The expected effects of retention interval and interference tasks on emotional recognition memory during consolidation in E1 were not found. However, highly-arousing negative words were more poorly recognized and responded to more liberally than neutral ones. Other cognitive factors that might be effective at encoding were tested in E2. The expected effects of presentation style and the semantic relatedness of encoding lists were not found, but there was a significant emotional effect on emotional recognition memory in E2.

Overall, this study did not find any support for the potential variables that were previously shown to affect the consolidation (E1) or encoding (E2) of emotional items thereby leading to an emotional memory enhancement. The two experiments consistently indicated that neutral words were more easily recognized than highly-arousing negative words in contrast to expectations based on the previous literature. In addition, there was a liberal bias shift toward highly-arousing negative words. These results might be due to the use of signal detection analysis in contrast to most previous studies. These findings may suggest that response bias is more adaptive for emotional memory than memory accuracy (Lynn \& Barrett, 2014). 
Duygusal ve duygusal olmayan (nötr) uyaranlar bellekte kalıcılıkları bakımından birçok kez karşılaştırılmış ve genelde duygusal uyaranların daha iyi hatırlandıkları sonucuna varılmıştır (Bkz. Tyng, Amin, Saad ve Malik, 2017). Söz konusu farklılığın hangi etkenlerden kaynaklandığını açıklamak üzere farklı görüşler ileri sürülmüştür. Sağlamlaşma çalışmaları bilginin kodlanmasından sonraki süreçlere odaklanarak duygusal uyaranların bellekte daha fazla güçlendiğini, nötr uyaranların ise zayıfladı̆̆ını savunmaktadır (Cahill ve McGaugh, 1998; Dudai, 2004; McGaugh, 2018). Bilginin kodlanması aşamasını ele alan çalışmalar ise duygusal ve nötr uyaranların bu aşamada farklılaştıklarını ileri sürmektedir (Hatfield, Cacioppo ve Rapson, 1992; Schmidt ve Schmidt, 2016; Talmi ve Moscovitch, 2004). Bununla birlikte son y1llarda sinyal tespit analizi (Macmillan ve Creelman, 2005) kullanılarak yapılan bazı çalışmalar duygusal uyaranların aslında daha doğru hatırlanmadığını, daha ziyade bu uyaranlara yönelik olarak tepki yanlılığı gösterildiğini öne sürmüştür (Dougal ve Rotello, 2007). Dolayısıyla sağlamlaşma ve kodlama çalışmalarının duygusal uyaranlara bellek avantajı sağladığını öne sürdükleri değişkenlerin sinyal tespit analizi ile incelenmesi büyük bir öneme sahiptir. Alan yazına bakıldığında tepki yanlılı̆̆ını da göz önünde bulundurarak, hem sağlamlaşma hem de kodlama aşaması temelinde duygusal ve nötr uyaran belleğinin ne şekilde farklılaştığının geniş kapsamda değerlendirilmediği görülmektedir. Bu çalışmanın amac1, söz konusu farklılaşmayı test etmek üzere sağlamlaşma ve kodlama aşamalarında etkili olduğu öne sürülen değişkenleri tepki yanlılığını da göz önünde bulundurarak incelemektir. Bu doğrultuda iki ayrı deney yapılmıştır, birinci deneyde sağlamlaşma aşaması test edilmiş ve bu deney sonucunda ortaya çıkan soruları test etmek üzere ikinci deneyde kodlama aşaması incelenmiştir.

\section{Duygu ve Bellek}

Bellek çalışmaları daha çok Duygunun Döngüsel Modeli (Circumplex Model; Russell, 1980) üzerinde yoğunlaşmaktadır. Bu modele göre duygusal durumlar iki temel nörofiziksel sistemden kaynaklanmaktadır; bunlardan biri değerlikle, diğeri ise uyarılmışlıkla ilişkilidir. Değerlik bir uyaranın veya olayın olumsuzdan olumluya doğru bir skalada haz değerini gösterirken uyarılmışlık şiddetini belirtmektedir. Hem uyarılmışlık hem de değerlik bakımından etki yaratmayan olaylar ise nötr olarak kabul edilmektedir. Mevcut çalışmada birçok nörolojik ve klinik çalışmayla daha fazla tutarlı olması nedeniyle (Posner, Russell ve Peterson, 2005) Duygunun Döngüsel Modeli temel alınmış ve duygusal uyaran tanımı Döngüsel Model üzerinden yapılmıştır. 


\section{Duygusal Bellek ve Sağlamlaşma Süreci}

Sağlamlaşma, öğrenilen bilginin bellekte zaman geçtikçe kalıcı ve dayanıklı hale gelmesi olarak tanımlanmaktadır (Dudai, 2004). Bu süreç bilginin kodlanmasından sonraki ilk dakikaları ya da yıllar süren bir zaman aralığını kapsayabilmektedir (Lechner, Squire ve Byrne, 1999). Cahill ve McGaugh'un (1998) öne sürdükleri modülasyon teorisine göre sağlamlaşma sürecinde gerçekleşen amigdala ve hipokampüs arasındaki etkileşimler duygusal bilgiye bellek avantajı sağlamaktadır. Bu teori amigdalanın duyguyla ilintili olarak aktive olması ve bellekle ilgili diğer beyin bölgelerini de etkilemesi sonucunda duygusal uyaranların zaman geçtikçe bellekte daha kalıcı hale geldiğini savunmaktadır (McGaugh, 2004). Sharot ve Yonelinas (2008) tarafından yapılan çalışma da duygusal uyaranların zaman geçtikçe unutulmaya karşı direnç kazandığı görüşünü desteklemektedir. Söz konusu çalışmada uyarılmışlığı yüksek negatif resimlerle, nötr resimlerin karışık olarak yer aldığı bir liste ikiye bölünerek iki karışık liste elde edilmiş ve katılımc1lara listelerin biri ilk gün diğeri ise ikinci gün sunulmuştur. İkinci gün, ikinci listenin de sunumundan sonra yapılan tanıma testinde katılımcıların 24 saat önce çalıştıkları listedeki duygusal resimleri nötr resimlerden daha iyi tanıdıkları, fakat beş dakika önce çalıştıkları listedeki duygusal ve nötr resimleri eşit derecede iyi tanıdıkları bulunmuştur. Sharot ve Yonelinas (2008) bu çalışma ile sadece birinci listede görülen duygunun bellek avantajının kodlamadan sonraki zamansal süreçte ortaya çıktığını desteklemişlerdir.

Sonuç olarak sağlamlaşma çalışmaları duygusal bilginin zaman geçtikçe bellekte daha kalıcı hale geldiğini öne sürmektedir. Bu durumda duygusal bilginin bellekte kalıcı hale gelmesi için gerekli zaman aralığının ne olduğu sorusu gündeme gelmektedir.

\section{Sağlamlaşma Aşaması ve Zaman Aralıkları}

Belleğe yeni girmiş olan bilgi hassas durumdadır ve sağlamlaşma aşamasındaki bu hassas dönem sonradan gelen uyaranların işlenebilmesi için ödenen bir bedel olarak değerlendirilmektedir (Dudai, 1996). Bununla birlikte belleğin ne kadar süreye kadar hassas olduğu konusu net değildir. Park (2005) öğrenmeden sonraki 2 dakika, 45 dakika, 1 gün ve 1 günden uzun olmak üzere farklı zaman aralıklarının bellek üzerindeki etkilerini incelediği bir meta-analiz çalışması yapmıştır. Bu çalışmada zaman aralığının belleği etkilediği ve belleğe yeni girmiş bilginin 20. dakikaya kadar hassas durumda olduğu ifade edilmiştir. Öte yandan, Nielson ve Powless (2007) sağlamlaşma etkisinin 30. dakikada ortaya çıktığını belirtmişlerdir. Sonuç olarak sağlamlaşma için kritik bir zaman 
aralığının olduğu tahmin edilse de araştırmacılar zaman aralıkları için belirli bir süre üzerinde uzlaşmış değillerdir (Lechner ve ark., 1999). Ayrıca, sağlamlaşma sürecinde zaman geçtikçe duygusal ve nötr uyaranlar bellekte aynı şekilde korunmamaktadır. Duygusal uyaranlar zaman geçtikçe bellekte daha sağlam hale gelirken, nötr uyaranların gittikçe daha çok güçsüzleştiği ve unutulduğu savunulmaktadır (Bkz. McGaugh, 2018). Kleinsmith ve Kaplan (1963) duygusal ve nötr uyaranlar arasındaki bu farklılaşmanın sağlamlaşma sürecinin 20. dakikasında ortaya çıktığını ileri sürmüşlerdir.

Bahsedilen bulgular 1şığında, bu çalışmanın birinci deneyinde duygusal ve nötr uyaranlara ilişkin tanıma performansının zaman aralığına göre ne şekilde farklılaştığını test etmek hedeflenmiştir. Bu amaçla, 10 dakika, 30 dakika ve 1 saat olmak üzere üç farklı zaman aralığı kullanılmasına karar verilmiştir.

\section{Sağlamlaşma Aşamasında Karıştırıcı Görev Etkisi}

Sağlamlaşma aşamasında belleğin hassas olması ve zaman geçtikçe güçlenmesi bu hassas dönemde meydana gelen olayların sağlamlaşma sürecini etkilemesine neden olmaktadır. Örneğin, sağlamlaşma için kritik bölgelerde protein sentezini engellemek, öğrenme sonrası başka bir görev yapmak ya da yeni bir şey öğrenmek bilginin bellekte sağlamlaşması üzerinde bozucu etki yaratabilmektedir (Been, Jans ve De Weerd, 2011; Robertson, 2012). Öte yandan bu bozucu etki duygusal ve nötr uyaranlar için aynı olmayabilmekte, duygusal ve nötr bilgiler bu manipülasyonlara karşı farklı şekilde direnç gösterebilmektedir. Cocenas-Silva, Bueno ve Droit-Volet (2013) konuyla ilgili olarak yaptıkları çalışmada duygusal uyaranların kodlamadan sonra gelen karıştırıcı (interference) göreve karşı daha dirençli olduğunu ve zamanın geçmesiyle birlikte daha iyi sağlamlaştığını göstermişlerdir.

Sonuç olarak, sağlamlaşma aşamasında duygusal ve nötr bilgi belleğinin farklılaşması zaman aralığının yanı sıra, öğrenme sonrası meydana gelen olaylardan ne derece etkilendikleriyle de bağlantılı olabilmektedir. Buradan hareketle, bu çalışmanın amacı duygusal ve nötr uyaranlara ilişkin tanıma belleğinin sağlamlaşma aşamasında nasıl farklılaştığını test etmek üzere farklı zaman aralıkları ve karıştırıcı görev değişkenlerinin incelenmesidir. Bununla birlikte, önceki birçok çalışmadan farklı olarak tepki yanl1lığının göz önünde bulundurulması amaçlanmış ve bu nedenle de sinyal tespit analizi kullanılmıştır. Bu amaç doğrultusunda çalışmanın birinci deneyi yapılmıştır. 


\section{DENEY 1}

Bu deneyde sağlamlaşma aşamasında duygusal ve nötr kelimelere ilişkin tanıma performansının nasıl farklılaştığı test edilmiştir. Bu amaçla öğrenme ve test arasında gerçekleşen sağlamlaşma sürecinde bağımsız değişkenler olarak farklı zaman aralıklarının ve karıştırıcı bir görevin verilmesinin etkisi incelenmiştir. Bu deneyde öne sürülen hipotezler şu şekildedir:

$H_{1}$ : Duygusal kelimelere ilişkin tanıma performansı nötr uyaranlardan a) 10. dakikada farklılaşmayacak, b) 30. dakikada daha iyi olacak ve c) 60. dakikada bu fark artacaktir.

$H_{2}$ : Karıştırıcı bir görev verilmesi duygusal ve nötr uyaranlara ilişkin 30. ve 60. dakikada görülmesi beklenen tanıma performanslarının farklılaşmasını artıracaktır.

\section{YÖNTEM}

\section{Katılımcılar}

Deneye Ege bölgesindeki bir devlet üniversitesinde lisans eğitimi görmekte olan 27'si erkek, 93'ü kadın olmak üzere toplamda 120 öğrenci $\left(O r t_{\text {yas }}=21.37, S S=2.14\right)$ katılmıştır.

\section{Veri Toplama Araçları}

Uyaranların Seçilmesi. Çalışmada 60 nötr ve 60 uyarılmışlığ 1 yüksek negatif olmak üzere toplam 120 kelime kullanılmıştır. Kelimelerin tamamı Kapucu, Kılıç, Özkılıç ve Sarıbaz’ın (2018) Türkçe kelime norm çalışmasındaki kelimelerden seçilmiştir. Yukarıda açıklandığı gibi duygusal uyaran tanımı Döngüsel Model (Russel, 1980) üzerinden yapıldığı için duygusal uyaran olarak uyarılmışlığı yüksek negatif kelimeler kullanılmıştır. Nötr kelimelerin (örn., lehçe, teori, kimyon) değerlik (Ort. $=4.84, S S=0.72$ ) ve uyarılmışlık (Ort. $=4.35, S S=0.66)$ düzeyleri 9'lu likert $(1=$ Çok olumsuz, $9=$ Çok olumlu) ölçek temel alınarak 2 ile 6 puanları arasında tutulmuştur. Uyarılmışlığı yüksek negatif kelimelerin (örn., kabus, dehşet, cenaze) 9'lu likert ölçek üzerinden ( 1 = Çok düşük, $9=$ Çok yüksek) değerlik düzeyi 3.5 değerinin altında $($ Ort. $=2.00, S S=0.46)$, uyarılmışlık düzeyi ise 6 değerinin üzerinde $(O r t .=6.47, S S=0.39)$ tutulmuştur. Duygusal ve nötr kelimeler Yazılı Türkçe’nin Kelime Sıklı̆̆ı Sözlüğü (Göz, 2003) kitabı referans alınarak dilde kullanılma sıklığı açısından kontrol edilmiş ve ayrıca kelime uzunlukları bakımından dengelenmiştir. Yüz yirmi kelimelik havuzdan beş defa 30 nötr 
ve 30 uyarılmışlığ1 yüksek negatif olmak üzere 60 kelime seçkisiz şekilde seçilmiş ve kodlama aşamasında sunulmak üzere beş farklı sunum listesi oluşturulmuştur. Böylece kodlama ve test aşamasında sunulacak kelimeler katılımcılar arasında dengelenmiştir. Katılımcılar kodlama aşamasında bu beş listeden birine seçkisiz olarak atanmışlardır. Tanıma testi aşamasında ise kodlama aşamasında sunulan 60 eski kelime ile kalan 30 nötr ve 30 uyarılmışlığı yüksek negatif yeni kelime olmak üzere toplam 120 kelime sunulmuştur. Tanıma testi aşamasında öncelik ve sonralık etkisini kontrol etmek için listelerin başına ve sonuna ikişer dolgu kelimesi ${ }^{1}$ eklenmiş ve bu kelimelere ilişkin tanıma performansı analize dahil edilmemiştir.

Karıştırıcı Görev. Bellek sağlamlaşması sürecini engellemek amacıyla DeSchepper ve Treisman (1996) tarafından geliştirilen şekil eşleme görevi (shape matching task) kullanılmıştır. Ortalama sekiz dakika süren bu görevde bilişsel kontrol ve çeldiricilere yönelik direnç test edilmektedir. Görev, kontrol ve deneysel denemelerden oluşmaktadır. Kontrol denemelerinde katılımcılardan ekranda gördükleri iki ayrı şeklin aynı olup olmadığını belirtmeleri istenmektedir. Deneysel denemelerde ise çeldirici bir şekil de sunulmakta ve katılımcılardan bu şekli göz ardı etmeleri istenmektedir. Bağımlı değişken olarak kontrol ve deneysel denemelerdeki doğru tepki sayısı ve tepki hızı karşılaştırılmaktadır. Bununla birlikte, katılımcıların bu görev sırasında gösterdiği performans deneyin hipotezleriyle ilişkili olmadığından analiz kısmında dikkate alınmamıştır.

Demografik Bilgi Formu. Katılımcıların yaş ve cinsiyet bilgileri bir form ile alınmıştır. Katılımcılar formu bilgisayar ortamında doldurmuşlardır.

\section{İşlem}

Öncelikle katılımcılar deneyden önce gönüllü katılım onam formunu okumuş ve imzalamışlardır. Kelime sunumları ve test aşaması açık kaynak kodlu bir deney yazılımı olan Open Sesame (Mathôt, Schreij ve Theeuwes, 2012) aracılığıyla gerçekleştirilmiştir. Katılımcılar önceden oluşturulmuş beş kelime listesinden birine seçkisiz olarak atanmışlardır. Katılımcılar ilk olarak ekrana gelen demografik bilgi formunu doldurmuşlardır. Sonrasında da 30 nötr ve 30 uyarılmışlığı yüksek negatif kelime seçkisiz olarak sunulmuş ve aynı kelime grubundan üçten fazla kelime art arda sunulmamıştır. Katılımcılara ekrana gelecek kelimelere dikkat etmeleri söylenmiş, fakat yapılacak bellek testine ilişkin bilgi verilmemiştir. Deney sorumlusu gerekli bilgileri verip kelime sunumları

1 Dolgu kelimesi olarak iki tane nötr ve iki tane uyarılmışlı̆̆ yüksek negatif kelime seçilmiştir. Bellek çalışmalarında, katılımcıların ilk gördükleri (öncelik etkisi) ve son gördükleri (sonralık etkisi) kelimeleri daha iyi hatırlama yanlılıkları bu şekilde dolgu kelimeler kullanılarak kontrol edilmeye çalışılmaktadır. Bu kelimelerin deneyde kullanılan diğer kelimelerden tek farkı analizde kullanılmayacak olmalarıdır. 
bittikten sonra çağrılmak üzere katılımcıyı deney odasında yalnız bırakmıştır. Bu şekilde sunum aşamasında katılımcının yalnız kalması ve deney sorumlusunun varlığından dolayı dikkatinin dağılmaması amaçlanmıştır. Sunum bittikten hemen sonra, sağlamlaşma sürecini engellemek amacıyla katılımcıların yarısına yaklaşık 8 dakika süren şekil eşleme görevi verilmiş, diğer yarısına ise herhangi bir görev verilmemiş ve laboratuvar dışında vakit geçirmeleri istenmiştir. Karıştırıcı görev alan ve almayan 60'ar katılımcı üç zaman aralığı (10 dakika, 30 dakika ve 1 saat) grubuna seçkisiz şekilde ve eşit sayıda atanmıştır. Katılımcılara, atandıkları zaman aralığı grubuna göre yeterli süre geçtikten sonra tanıma testi yapılmıştır. Tanıma testinde sunum aşamasında gösterilen 60 eski kelime ile geriye kalan sunulmamış 60 yeni çeldirici kelime seçkisiz şekilde sunulmuştur. Tanıma testinde her katılımc1 120 kelimenin eski ya da yeni olduğunu değerlendirmiştir. Katılımcılardan ekranda gördükleri kelimenin yeni mi (sunum listesinde olmayan), yoksa eski mi (sunum listesinde olan) olduğunu ' $1=$ Kesinlikle yeni' ile ' $6=$ Kesinlikle eski' arasındaki likert ölçek üzerinden değerlendirmeleri istenmiştir. Sekiz kelimelik bir deneme bölümü deney sorumlusu ile gerçekleştirilmiştir. Bu sırada katılımcılardan ne kadar emin olduklarını göz önünde bulundurarak değerlendirmelerini yapmaları vurgulanmıştır. Öncelik ve sonralık etkisi için kullanılan dört dolgu kelimeye ek olarak dört yeni kelime deneme bölümünde kullanılmış, ancak sonuçları analize dahil edilmemiştir. Deney verisi 2017-2018 akademik yılının ikinci döneminde toplanmıştır.

\section{Araştırma Deseni}

Çalışmanın deney deseni 3 (zaman aralığı: 10 dakika, 30 dakika veya 1 saat) x 2 (karıştırıcı görev: var veya yok) x 2 (kelime grubu: uyarılmışlı̆̆ yüksek negatif kelimeler ve nötr kelimeler) karışık deney desenidir. Sinyal tespit analizi (Macmillan ve Creelman, 2005) kullanılarak katılımcıların isabet ve yanlış alarm oranları, duyarlılık ( $A U$ $C$-Area Under the Curve) ve tepki yanlılığı (c) parametreleri hesaplanmış ve bu değerler bağımlı değişkenler olarak ayrı ayrı analize sokulmuştur.

\section{Veri Analizi}

Deneyden elde edilen veriler IBM SPSS23 paket program kullanılarak analiz edilmiştir. Yürütülen karışık desenler için ANOVA analizinin tüm varsayımları karşıllanmıştır. Anlamlı etkileşimler için yapılan izleme testlerinde Bonferroni düzeltmesi uygulanmış ve sonuçlar düzeltilmiş şekilde raporlanmıştır. Verinin tanımlayıcı (descriptive) değerleri aşağıdaki tabloda verilmiştir².

2 Değeri 1 olan İsabet Oranları (Uyaran Sayısı + 0,5) / (Uyaran Sayısı + 1) formülüyle ve değeri 0 olan Yanlış Alarm oranları $(Y A+0,5) /($ yaran Sayısı +1$)$ formülüyle düzeltilmiştir (Snodgrass ve Corwin, 1988). 
Tablo 1. Değişkenlere Ait Ortalama ve Standart Sapma Değerleri

\begin{tabular}{|c|c|c|c|c|c|}
\hline & & Ketleyici G & jrev Alanlar & Ketleyici C & örev Almayanlar \\
\hline & & Nötr Kelimeler & $\begin{array}{c}\text { Uyarılmışlığı } \\
\text { Yüksek Negatif } \\
\text { Kelimeler }\end{array}$ & Nötr Kelimeler & $\begin{array}{l}\text { Uyarılmışlığı Yüksek } \\
\text { Negatif Kelimeler }\end{array}$ \\
\hline & & $\bar{X}$ & $\bar{X}$ & $\bar{X}$ & $\bar{X}$ \\
\hline İsabet Oranları & $10 \mathrm{dk}$ & $.69(.17)$ & $.81(.11)$ & $.69(.13)$ & $.78(.12)$ \\
\hline & $30 \mathrm{dk}$ & $.74(.17)$ & $.83(.10)$ & $.65(.16)$ & $.74(.17)$ \\
\hline & 1 saat & $.66(.18)$ & $.82(.11)$ & $.65(.20)$ & $.77(.14)$ \\
\hline Yanlış Alarm Oranları & $10 \mathrm{dk}$ & $.13(.10)$ & $.33(.15)$ & $.13(.08)$ & $.38(.15)$ \\
\hline & $30 \mathrm{dk}$ & $.11(.10)$ & $.31(.18)$ & $.15(.11)$ & $.36(.17)$ \\
\hline & 1 saat & $.16(.09)$ & $.39(.17)$ & $.14(.10)$ & $.40(.18)$ \\
\hline Duyarlılık Puanları & $10 \mathrm{dk}$ & $.82(.11)$ & $.79(.08)$ & $.84(.09)$ & $.78(.10)$ \\
\hline & $30 \mathrm{dk}$ & $.86(.08)$ & $.82(.09)$ & $.79(.10)$ & $.78(.08)$ \\
\hline & 1 saat & $.81(.10)$ & $.79(.08)$ & $.80(.12)$ & $.76(.11)$ \\
\hline Yanlılık Puanları & $10 \mathrm{dk}$ & $.37(.44)$ & $-.22(.32)$ & $.36(.31)$ & $-.26(.34)$ \\
\hline & $30 \mathrm{dk}$ & $.35(.55)$ & $-.24(.44)$ & $.37(.34)$ & $-.19(.54)$ \\
\hline & 1 saat & $.33(.35)$ & $-.34(.43)$ & $.47(.39)$ & $-.24(.48)$ \\
\hline
\end{tabular}

Not. $\bar{X}$, ortalamayı, parantez içinde verilen değerler ise standart sapmayı belirtmektedir

Katılımcıların tanıma belleği performansı sinyal tespit analizi kullanılarak değerlendirilmiştir. Sinyal tespit analizinde kullanılan istatistiksel yöntemler katılımcıların tanıma doğruluğu ve yanıtlama stilleri arasında ayrım yapma olanağı sağlamaktadır (Macmillan ve Creelman, 2005). Tanıma görevinde tanıma doğruluğu (veya metnin geri kalanında kullanılacak ifadeyle duyarlılık), katılımcının kodlama aşamasında gördüğü eski bir uyaranı, tanıma testi aşamasında diğer çeldirici yeni uyaranlardan doğru şekilde ayırt etmesi anlamına gelmektedir. Bu amaçla katılımcıların duyarlılık performansı isabet (eski uyaranlara verilen "eski”" yanıtları) ve yanlış alarm (yeni uyaranlara verilen “eski” yanıtları) tepkileri birlikte göz önünde bulundurularak hesaplanmaktadır. Ayrıca katılımcılar tanıma testi sırasında farklı karar verme kriterleri belirleyerek tepki yanlılı̆̆ gösterebilir ve daha liberal ("eski” deme eğilimi) veya daha muhafazakar ("yeni” deme eğilimi) tepkiler verebilirler.

Sinyal tespit analizi kullanılarak ROC eğrileri elde edilmektedir (Macmillan ve Creelman, 2005). ROC eğrileri her katılımcı ve koşul için isabet ve yanlış alarm oranlarının güven aralıklarına göre kümülatif olarak karş1lıklı eksenlere yerleştirilmesiyle oluşturulmaktadır. Bu eğriler katılımcıların tanıma belleği performansını göstermek için kul- 
lanılmaktadır. Bu çalışmada ROC eğrisinin altında kalan alan $(A U C)$ katılımcıların duyarlı1ık performansının ölçüsü olarak değerlendirilmiştir. ROC alanında daha yukarıda olan eğriler daha yüksek duyarlılığı ifade etmektedir.

\section{BULGULAR}

\section{İsabet ve Yanlıs Alarm Oranları}

Karışık desenler için ANOVA analizinin sonuçlarına göre kelime grubunun hem isabet $\left(F(1,114)=109.71, p<.001, \eta_{\mathrm{p}}{ }^{2}=.49\right)$ hem de yanlış alarm oranları $(F(1,114)=$ 287.24, $p<.001, \eta_{\mathrm{p}}^{2}=.72$ ) üzerinde anlamlı etkisi bulunmuştur (Bkz. Şekil 1). Öte yandan isabet oranları için zaman aralığının $(F(2,114)=2.47, p>.05)$ veya karıştırıcı göre$\operatorname{vin}(F(1,114)=.20, p>.05)$ ana etkisi anlamlı bulunmamış ve bu iki değişken arasında anlamlı bir etkileşim görülmemiştir $(F(2,114)=.24, p>.05)$. Aynı şekilde yanlış alarm oranları için zaman aralığının $(F(2,114)=.77, p>.05)$ veya karıştırıcı görevin $(F(1$, $114)=1.30, p>.05)$ ana etkisi anlamlı bulunmamış ve bu iki değişken arasında anlamlı bir etkileşim görülmemiştir $(F(2,114)=.17, p>.05)$.

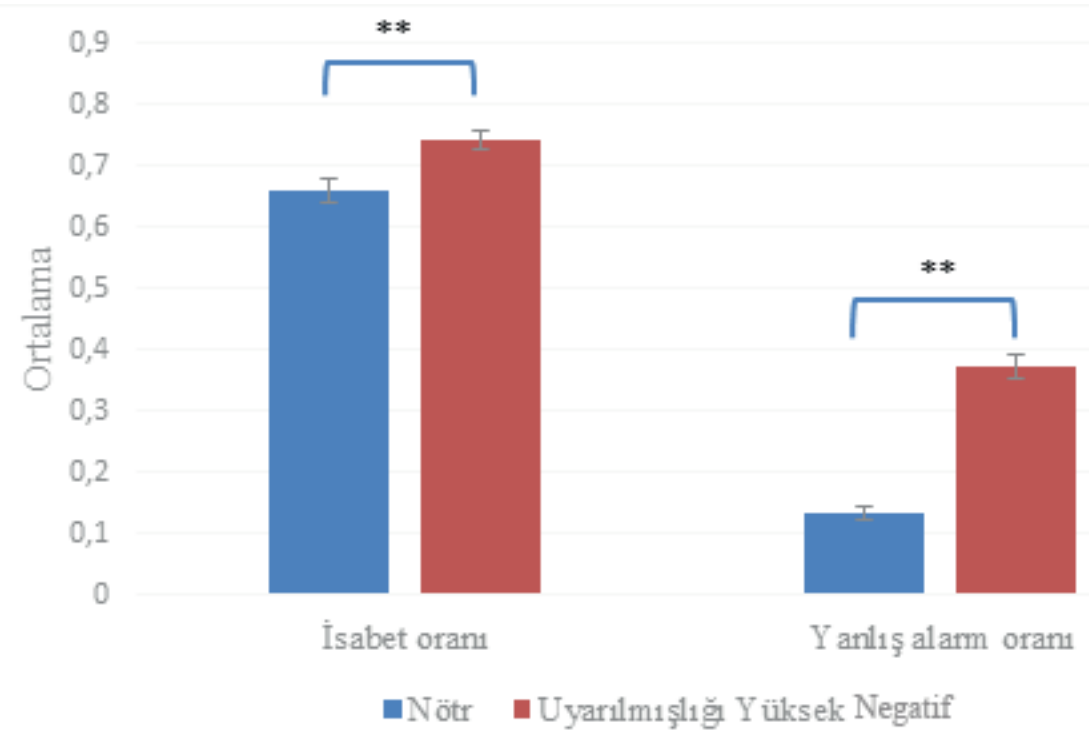

Şekil 1. Kelime Gruplarına (Nötr ve Uyarılmışlığı Yüksek Negatif) Göre İsabet ve Yanlış Alarm Oranları

Sonuçlar hem isabet hem de yanlış alarm oranlarının uyarılmışlığı yüksek negatif kelimeler için daha fazla olduğunu göstermiştir. Bu sonuçlar duygunun duyarlılığı artır- 
maktan ziyade "eski" deme yanlılığına sebep olmasından kaynaklanabileceğinden, tanıma performansını doğruluk ve yanlılık ölçümlerini ayrı ayrı göz önünde bulundurarak test etme imkanı sağlayan sinyal tespit analizleri gerçekleştirilmiştir.

\section{Sinyal Tespit Analizleri ve ROC Eğrileri}

ROC eğrilerine göre (Bkz. Şekil 2) nötr kelimelere ait eğrinin sol üst köşeye daha yakın olduğu görülmektedir.

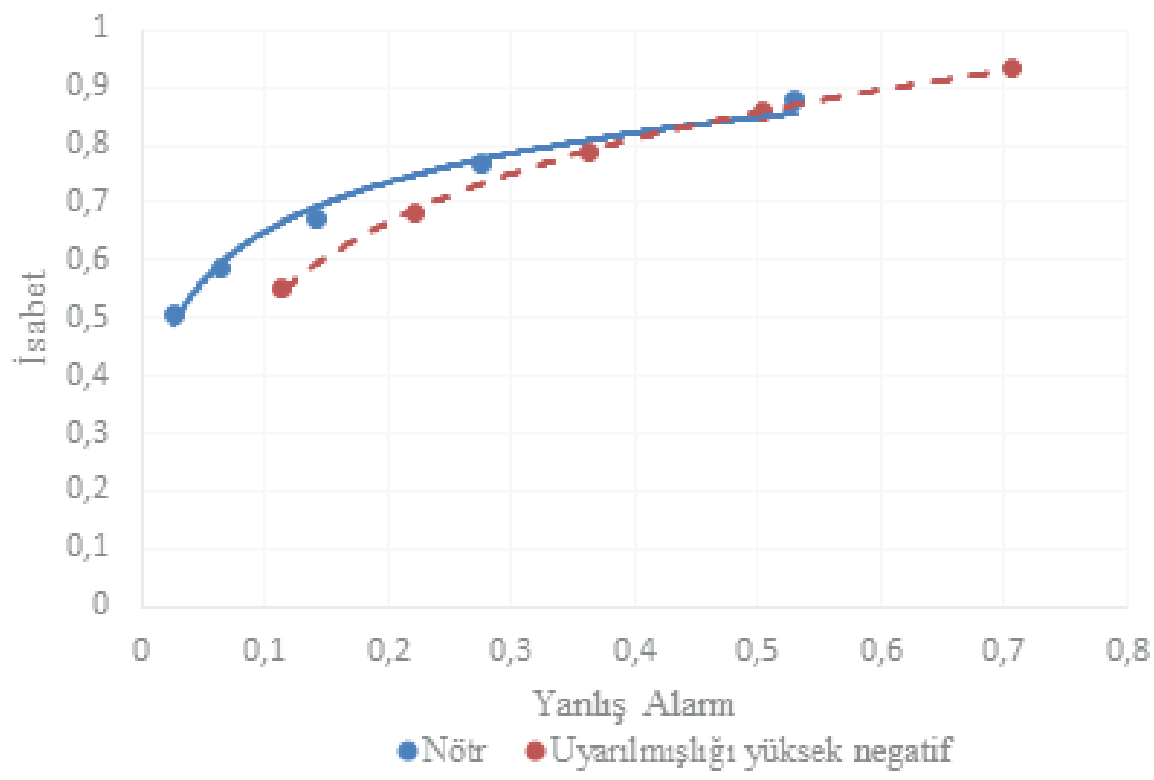

Şekil 2. Kelime Gruplarının (Nötr ve Uyarılmışlığı Yüksek Negatif) ROC Eğrileri

Bu durum katılımcıların tanıma duyarlılı̆̆ının, uyarılmışlığı yüksek negatif kelimelere kıyasla, nötr kelimeler için daha yüksek olduğunu göstermektedir. Bunun yanı sıra, uyarılmışlığı yüksek negatif kelimelere ait eğrinin daha içeriden başladığı görülmektedir. Aynı güven aralığı için hem isabet hem de yanlış alarm oranları, nötr kelimelere k1yasla bu kelimeler için daha yüksektir ve bu da bu kelimelere karşı liberal tepki yanlılığı gösterilmiş olduğuna işaret etmektedir. ROC eğrilerinin gözlenmesiyle yapılan bu çıkarımları istatistiksel olarak desteklemek amacıyla her bir katılımcı için duyarlılık (AUC) ve yanlılık (c) parametreleri hesaplanmış ve bu değerler bağımlı değişken olarak analizlere dahil edilmiştir. Böylelikle tanıma doğruluğu ve tepki yanlılığg hem isabet hem de yanlış alarm değerleri göz önünde bulundurularak hesaplanmıştır. 
Tanıma Doğruluğu/Duyarlılığı (AUC; Area Under the ROC Curve). Yürütülen karışık desenler için ANOVA testi ile kelime grubunun tanıma doğruluğu üzerinde anlamlı bir etkisi bulunmuştur $\left(F(1,114)=23.91, p<.001, \eta_{\mathrm{p}}{ }^{2}=.17\right)$. Nötr kelimeler $($ Ort. $=.82, S S=.01)$ uyarılmışlığ1 yüksek negatif kelimelerden $($ Ort. $=.79, S S=.01)$ daha doğru tanınmışlardır. Bununla birlikte zaman aralığının $(F(2,114)=.47, p>.05)$ veya karıştırıcı görevin $(F(1,114)=.31, p>.05)$ tanıma doğruluğu üzerinde anlamlı bir etkisi bulunmamıştır. Ayrıca bu iki değişken arasında anlamlı bir etkileşim görülmemiş$\operatorname{tir}(F(2,114)=.91, p>.05)$.

Tepki Yanlılığı (c). Yürütülen karışık desenler için ANOVA testi, kelime grubunun tepki yanlılığı üzerinde anlamlı bir etkisi olduğunu göstermiştir $(F(1,114)=320.82, p<$ $\left..001, \eta_{\mathrm{p}}^{2}=.74\right)$. Katılımcılar, uyarılmışlığ 1 yüksek negatif kelimelere (Ort. $=-.25, S S=$ $.04)$, nötr kelimelere (Ort. $=.37, S=.04)$ kıyasla daha fazla "eski” deme yanlılı̆̆ göstermişlerdir ${ }^{3}$. Bununla birlikte, zaman aralığının $(F(2,114)=1.18, p>.05)$ veya karıştırıcı görevin $(F(1,114)=.05, p>.05)$ tepki yanlılığı üzerinde anlamlı bir etkisi bulunmamış ve bu iki değişken arasında anlamlı bir etkileşim görülmemiştir $(F(2,114)$ $=.12, p>.05)$.

\section{TARTIŞMA}

Birinci deneyde farklı zaman aralıklarının ve karıştırıcı bir görevin verilmesinin duygusal tanıma belleği üzerindeki etkisi test edilmiştir. Elde edilen sonuçlar uyarılmışlığ1 yüksek negatif kelimelere ve nötr kelimelere ilişkin tanıma performansının birbirinden farklılaştığını ancak bu farklılaşmanın çeşitli zaman aralıklarından $\left(H_{1}\right)$ veya karıştırıcı görevden $\left(H_{2}\right)$ etkilenmediğini göstermiştir. Daha da önemlisi, yaygın olarak elde edilen bulguların aksine (Bkz. Tyng ve ark., 2017), nötr kelimelerin uyarılmışlığı yüksek negatif kelimelerden daha iyi tanındığı görülmüştür. Böyle bir bulguyu bağlantılı alan yazın açısından birkaç şekilde açıklamak mümkündür.

Birincisi, duygusal uyaranların daha iyi hatırlandığını savunan birçok çalışmadan (örn., Cocenas-Silva ve ark., 2013; Nielson ve Powless, 2007) farklı olarak bu deneyde sinyal tespit analizi kullanılmıştır. Sinyal tespit analizi kullanan bazı çalışmalar duygusal uyaranların aslında daha iyi tanınmadıklarını ve çalışmalarda elde edilen yüksek tanıma oranlarının sadece tepki yanlılığından kaynaklandığını savunmaktadır (örn.,

3 Yanlılık (c) ölçümlerinde negatif değerler liberal tepki yanlılığını, pozitif değerler ise muhafazakar tepki yanlılı̆̆ını göstermektedir. 
Dougal ve Rotello, 2007; Kapucu, Rotello, Ready ve Seidl, 2008). Bu yaklaşıma göre tanıma testlerinde verilen bir duygusal uyaran, kodlama aşamasında sunulmuş olsa da olmasa da katılımcılar bu uyaranı daha önce gördüklerini belirtme yönünde bir tepki yanlılığı göstermektedirler. Dolayısıyla duygusal uyaranların aslında her zaman nötr uyaranlardan daha doğru şekilde tanınmayabileceği, çünkü bu uyaranlara yönelik olarak liberal tepki yanlılığ 1 yapıldığı savunulmaktadır. Bununla birlikte tek başına isabet oranlarına bakıldığında uyarılmışlı̆̆ı yüksek negatif kelimelerin daha yüksek puana sahip olduğu görülmektedir. Bu durum sinyal tespit analizi kullanılmayan önceki çalışmalarda neden duygusal uyaranların daha iyi hatırlandığı bulgusunun elde edildiğini açıklayabilir.

İkinci olarak ise, birinci deneyde sağlamlaşma aşamasına odaklanılırken kodlama aşaması üzerinde durulmamıştır. Bu nedenle, kodlama aşamasında gerçekleşen süreçlerin tanıma performansını etkilemiş olabileceği düşünülebilir. Sadece sağlamlaşma süreçlerine odaklanan çalışmalar kodlama aşamasında ortaya çıkan bellek farklılıklarını açıklamakta yetersiz kalabilmektedir (Talmi, Luk, McGarry ve Moscovitch, 2007).

\section{DENEY 2}

Birinci deneyde, duygunun tanıma doğruluğu üzerinde anlamlı bir etkisinin olduğu ve beklenilenin aksine nötr kelimelerin uyarılmışlı̆̆ı yüksek negatif kelimelerden daha iyi tanındıkları görülmüştür. Ayrıca sağlamlaşma sürecinin bu durum üzerinde bir etkiye sahip olmadığg görülmüştür. Dolayısıyla, birinci deneyden elde edilen sonuçlar incelendiğinde, bu sonuçlar üzerinde kodlama aşamasında gerçekleşen bilişsel süreçlerin etkili olup olmadığı sorusu ortaya çıkmıştır. Buradan hareketle, çalışmanın ikinci deneyinde bu soruyu test etmek amaciyla kodlama aşamasında etkili olabilecek bilişsel etkenler incelenmiştir.

\section{Kelime Listelerinin Sunum Şekli}

Birinci deneyin kodlama aşamasında duygusal ve nötr kelimeler karışık şekilde sunulmuştur. Bu sunum şeklinin taşıma (carryover) etkisine neden olabileceği ileri sürülmektedir (Schmidt ve Schmidt, 2016). Taşıma etkisine göre, duygusal uyaranların bellek üzerindeki etkisi kendileriyle birlikte sunulan nötr uyaranlara taşınabilmekte ve bunun sonucunda da nötr uyaranlar daha iyi hatırlanabilmektedir. Benzer şekilde Hatfield ve arkadaşları (1992) tarafından ortaya atılan duygusal bulaşma (emotional contagion) teorisine göre duygusal uyaranlar, kendileriyle birlikte sunulan nötr uyaranlara etkilerini 
bulaştırmakta ve onların daha iyi hatırlanmalarına neden olmaktadır. Ek olarak kodlama aşamasında uyaranların hızlı ve art arda sunulmasıyla duygusal uyaranların artırdığı kortizol seviyesinin nötr uyaranların daha iyi kodlanmasını sağlayabileceği ileri sürülmektedir (Talmi, 2013). Bunun sonucunda da karışık listelerde sunulan nötr uyaranlar, sadece duygusal veya sadece nötr kelimelerden oluşan tekli (pure) listelerde sunulan nötr uyaranlardan daha iyi hatırlanabilmektedir. Dolayısıyla birinci deneyde nötr kelimelerin daha iyi hatırlanmasının, kodlama aşamasında uyarılmışlığı yüksek negatif kelimelerle karışık şekilde sunulmaları sonucunda ortaya çıkmış olabileceği düşünülmüştür.

\section{Semantik İlişkisellik}

Birinci deneyde elde edilen bir diğer bulgu ise uyarılmışlığı yüksek negatif kelimelere yönelik olarak liberal tepki yanlılığı gösterilmesidir. Duygu, bellekte organizasyon işlevine sahiptir ve duygusal uyaranlar zihinde birtakım kategorileri temsil etmektedir. Bunun sonucunda da duygusal uyaranlar ilişkisiz nötr uyaranlara kıyasla birbirleriyle semantik olarak daha fazla ilişkiye sahiptir (Buchanan, Etzel, Adolphs ve Tranel, 2006; Talmi ve Moscovitch, 2004). Semantik ilişkiselliğin duygusal uyaranlara bellekte yüksek ulaşılabilirlik sağladığı ve bunun sonucunda da bu uyaranların daha iyi hatırlandıkları bulunmuştur (Tulving ve Pearlstone, 1966). Talmi ve Moscovitch (2004) çalışmalarında uyarılmışlığı yüksek negatif kelimelerin hatırlanmasında semantik ilişkiselliğin rolünü test etmişlerdir. Söz konusu araştırmada uyarılmışlığı yüksek negatif kelimeler, belli bir kategori oluşturan nötr kelimeler (örn., mutfak veya müzik ile ilgili kelimeler) ve birbiriyle ilişkisiz nötr kelimeler olmak üzere üç farklı kelime grubu sunulmuş ve katılımcıların hatırlama (recall) performansları ölçülmüştür. Sonuçlar duygusal kelimelerin, ilişkisiz nötr kelimelerden daha iyi hatırlandığını fakat kategorik nötr kelimelerden daha kötü hatırlandıklarını göstermiştir. Bu çalışmayla semantik ilişkiselliğin eşit olması durumunda duygusal uyaranların nötr uyaranlara kıyasla sahip olduğu bellek avantajının ortadan kalktığ 1 savunulmuştur (semantik ilişkiselliğin bir ölçek üzerinden nasıl ölçüldüğü mevcut çalışmanın yöntem kısmında açıklanmıştır). Uyaran olarak kelime yerine resim kullanıldığında da semantik ilişkiselliğin duygusal uyaranların daha iyi hatırlanmasında aracı role sahip olduğu sonucuna varılmıştır (Talmi, Schimmack, Paterson ve Moscovitch, 2007; Talmi ve ark., 2007). Öte yandan, White, Kapucu, Bruno, Rotello ve Ratcliff (2014) tarafından sinyal tespit analizi kullanılan bir çalışmada duygusal uyaranların birbirleriyle ilişkili olmalarının salt tanıma doğruluğu sağlama- 
dığı, daha ziyade liberal tepki yanlılığına neden olduğu gösterilmiştir. Bu çalışmanın birinci deneyinde de White ve arkadaşlarının (2014) çalışmasıyla tutarlı olarak, duygusal kelimelerin nötr kelimelere kıyasla daha doğru tanınmadığı fakat duygusal uyaranlara yönelik liberal tepki yanlılığının ortaya çıktığı görülmüştür. Buradan hareketle, nötr ve uyarılmışlığg yüksek negatif kelime gruplarının anlamsal ilişkisellik açısından eşitlenmesi durumunda duygusal kelimelere yönelik liberal tepki yanlılığının azalabileceği öne sürülmüştür.

Sonuç olarak kodlama aşamasında etkili olabilecek birtakım bilişsel etmenlerin etkisinin araştırılması amacıyla ele alınan ikinci deneyde kodlama aşamasında kullanılan sunum şekli (tekli veya karışık) ve semantik ilişkisellik (eşit veya eşit olmayan ${ }^{4}$ ) manipüle edilerek farklı sunum listeleri oluşturulmuştur. Tekli liste koşullarında uyarılmışlığ yüksek negatif ve nötr kelimeler iki ayrı liste olarak, karışık liste koşullarında ise karışık olarak sunulmuştur. Eşit semantik ilişkisellik koşullarında ise uyarılmışlığı yüksek negatif ve nötr kelimelerin semantik ilişkisellikleri eşitlenmiş, eşit olmayan semantik ilişkisellik koşullarında eşitlenmemiştir. Sonuç olarak sunum aşamasında katılımcılara sunulmak üzere dört farklı liste oluşturulmuştur: (1) Eşit derecede semantik ilişkili-tekli liste, (2) Eşit derecede semantik ilişkili-karışık liste, (3) Eşit olmayan semantik ilişkili-tekli liste, (4) Eşit olmayan semantik ilişkili-karışık liste. Deneyde öne sürülen hipotezler şu şekildedir:

$H_{3}$ : Sunum şekli kontrol edildiğinde birinci deneyde görülen nötr uyaranlara yönelik yüksek tanıma duyarlılı̆̆ı karışık listelere kıyasla tekli listelerde azalacaktır.

$H_{4}$ : Semantik ilişkisellik kontrol edildiğinde duygusal uyaranlara yönelik liberal tepki yanlılığı eşit semantik ilişkisellik koşulunda azalacaktır.

\section{YÖNTEM}

\section{Katılımcilar}

Deneye Ege bölgesindeki bir devlet üniversitesinde lisans eğitimi görmekte olan 5'i erkek, 55'i kadın olmak üzere toplamda $60\left(\right.$ Ort $_{\text {yas }}=19.82$, $\left.S S=1.86\right)$ öğrenci katılmıştir.

4 Eşitleme yöntem kısmında bahsedilen ön çalışma ile yapılmıştır. 


\section{Veri Toplama Araçları}

Semantik İlişkisellik Ön Çalışması ile Sunum Listelerinin Oluşturulması. Bu deneyde çalışmanın birinci deneyinde kullanılan kelimeler kullanılmıştır. Duygusal ve nötr kelimelerin semantik ilişki düzeylerini belirlemek üzere 23'ü erkek, 67'si kadın olmak üzere toplamda 100 katılımcının $\left(\right.$ Ort $\left._{\text {yas }}=22.23, S S=1.66\right)$ yer aldığ bir ön çalışma yapılmıştır. $\mathrm{Bu}$ ön çalışmada 120 kelimelik uyaran havuzu duygusal ve nötr kelimeler olmak üzere iki eşit gruba ayrılmıştır. Talmi ve Moscovitch'in (2004) izlediği yöntem örnek alınarak, her bir gruptaki 60 kelime kendi grubundaki diğer kelimelerle eşleştirilmiş ve 1770 kelime çifti oluşturulmuştur. Katılımcıların listelerden birini sonuna kadar sıkılmadan ve dikkati dağılmadan değerlendirmesinin güçlüğü göz önünde bulundurularak kelime çiftlerinden 10 ayrı liste oluşturulmuş ve her bir katılımcıya 177 kelime çifti sunulmuştur. Bu şekilde her bir kelime çifti 10 ayrı katılımcı tarafından değerlendirilmiştir. Her bir kelime çifti arasında ne düzeyde anlamsal ilişki olduğu 7'li likert ölçek üzerinde işaretlendikten sonra her bir kelime için bir semantik ilişkisellik puanı elde edilmiştir (Bkz. Talmi ve Moscovitch, 2004). Uygulanan bağımsız örneklemler $t$-testi sonuçlarına göre uyarılmışlığ 1 yüksek negatif kelimelerin semantik ilişkisellik düzeyi (Ort. $=3.68, S S=.72)$ belli bir kategoriye ait olmayan nötr kelimelerin semantik ilişkisellik düzeyinden $($ Ort. $=2.60, S S=.46)$ anlamlı şekilde daha yüksek bulunmuştur $(t(98)=9.82, p \leq .05)$. Bu sonuçlar, uyarılmışlığı yüksek negatif kelimelerin semantik ilişkisellik düzeylerinin kategorik olmayan nötr kelimelere göre daha yüksek olduğunu gösteren araştırmalarla (Talmi ve ark., 2007; White ve ark., 2014) tutarlıdır.

$\mathrm{Bu}$ puanlar kullanılarak duygusal ve nötr kelimelerin semantik ilişki düzeylerinin eşit olduğu bir sunum listesi oluşturulmuştur. Bu listeyi oluşturmak için semantik ilişki düzeyi en düşük 30 uyarılmışlığı yüksek negatif kelime (Ort. $=3.13$, SS $=0.54$ ) ve semantik ilişki düzeyi en yüksek 30 nötr kelime $(O r t .=2.95, S S=0.39)$ kullanılmıştır. Yürütülen bağımsız örneklemler $t$-testi sonucuna göre bu iki kelime grubunun (uyarılmışlığ1 yüksek negatif ve nötr) semantik ilişki değerleri arasında anlamlı bir fark bulunmamıştır $(t(53)=1.51, p>.05)$. Semantik ilişki düzeyinin etkilerini karşılaştırmak için hazırlanan diğer sunum listesinde ise uyarılmışlı̆̆ 1 yüksek negatif ve nötr kelimelerin semantik ilişki ortalamaları birbirlerinden farklı tutulmuştur $(t(58)=6.25, p<.001)$. Bu şekilde kodlama aşamasında sunulmak üzere semantik ilişkisellik açısından eşit olan ve olmayan iki farklı liste oluşturulmuştur. 
Tekli ve Karışık Sunum Listelerinin Oluşturulması. Nötr ve uyarılmışlığı yüksek negatif kelimelerin semantik ilişkisellikleri açısından eşitlendiği veya farklı tutulduğu iki ayrı liste oluşturulduktan sonra bu listelerin karışık veya tekli listelerde sunulması koşulları oluşturulmuştur. Karışık liste koşulunda 30 nötr ve 30 uyarılmışlı̆̆ı yüksek negatif kelime karışık şekilde sunulmuş ve aynı gruptaki kelimelerin üç defadan fazla art arda gelmemesi sağlanmıştır. Tekli liste koşulunda ise katılımcılara bir gruptaki kelimelerin hepsi sunulduktan sonra diğer gruptaki kelimeler sunulmuştur. Örneğin, kat1lımcılara önce 30 uyarılmışlığı yüksek negatif kelime, sonra da 30 nötr kelime sunulmuştur. Katılımcıların önce hangi gruptaki kelimeleri göreceği katılımcılar arasında dengelenmiştir.

Sonuç olarak semantik ilişkisellik ve sunum şekli manipüle edilerek dört farklı liste oluşturulmuştur: (1) Eşit semantik ilişkili-tekli liste, (2) Eşit semantik ilişkili-karışık liste, (3) Eşit olmayan semantik ilişki-tekli liste, (4) Eşit olmayan semantik ilişki-karışık liste. Eşit olmayan semantik ilişki-karışık liste koşulu için birinci deneyde karıştırıcı görev olmayan 10 dakika koşulunun verisi kullanılmıştır. Birinci deneyde farklı zaman aralıklarının anlamlı bir etkisi bulunmadığından bu deneyde sadece 10 dakika zaman aralığ1 kullanılmıştır. Sunum şeklinin etkisini test etmek üzere 1. ve 4. liste ile 2. ve 3. liste karşılaştırılmış, $H_{3}$ doğrultusunda karışık listelere kıyasla tekli listelerde tanıma duyarlılığının azalması beklenmiştir. Semantik ilişkiselliğin etkisini test etmek üzere ise 1 . ve 2. liste ile 3. ve 4. liste karşılaştırılmış, $H_{4}$ doğrultusunda uyarılmışlı̆̆ yüksek negatif kelimelere yönelik liberal tepki yanlılığının eşit semantik ilişkisellik koşullarında azalması beklenmiştir.

Demografik Bilgi Formu. Katılımcıların yaş ve cinsiyet bilgileri bir form ile alınmıştır. Katılımcılar formu bilgisayar ortamında doldurmuşlardır.

\section{İşlem}

Katılımcılar deneyden önce gönüllü katılım onam formunu okumuş ve imzalamışlardır. Birinci deneyde olduğu gibi bu deneyde de katılımcıların bellek performansı, tanıma testi ile bağımlı değişken olarak ölçülmüş ve sinyal tespit analizi ile değerlendirilmiştir. Deney verisi 2018-2019 akademik yılının birinci döneminde toplanmiştır.

Kelime sunumları ve test aşaması açık kaynak kodlu bir deney yazılımı olan Open Sesame (Mathôt ve ark., 2012) aracılı̆̆ıyla gerçekleştirilmiştir. Katılımcılar ilk olarak 
ekrana gelen demografik bilgi formunu doldurmuşlardır. Sonrasında ise katılımcılara ekrana gelecek kelimelere dikkat etmeleri söylenmiş, fakat yapılacak bellek testine ilişkin bilgi verilmemiştir. Deney sorumlusu gerekli bilgileri verip kelime sunumları bittikten sonra çağrılmak üzere katılımcıyı deney odasında yalnız bırakmıştır. Bu şekilde sunum aşamasında katılımcının yalnız kalması ve deney sorumlusunun varlığından dolayı dikkatinin dağılmaması amaçlanmıştır. Kelime sunumları bittikten sonra deneyin ikinci aşamasının yaklaşık sekiz dakika sonra başlayacağı bilgilendirmesi yapılıp bu süre boyunca katılımcılar serbest bırakılmışlardır. Katılımcılar yaklaşık sekiz dakika sonra tekrar odaya alınmış ve kelime sunumu üzerinden 10 dakika geçmesiyle katılımcılar tanıma testi aşamasına başlamışlardır. Katılımcılardan 20 kişi semantik ilişkiselliğin eşit olduğu tekli liste koşuluna, 20 kişi semantik ilişkiselliğin eşit olduğu karışık liste koşuluna, 20 kişi ise semantik ilişkiselliğin eşit olmadığı tekli liste koşuluna seçkisiz olarak atanmıştır. Tanıma testinde 60 eski kelimeyle birlikte 30 yeni uyarılmışlığ yüksek negatif kelime ve 30 yeni nötr kelime olmak üzere toplam 120 kelime sunulmuştur. Katılımcılardan ekranda gördükleri kelimenin yeni mi (sunum listesinde olmayan) yoksa eski mi (sunum listesinde olan) olduğunu ' 1 = Kesinlikle yeni' ile ' 6 = Kesinlikle eski’ arasındaki 6’lı likert ölçek üzerinden değerlendirmeleri istenmiştir. Birinci deneyde olduğu gibi bu deneyde de sekiz kelimelik bir deneme bölümü deney sorumlusu eşliğinde gerçekleştirilmiştir. Öncelik ve sonralık etkisi için kullanılan dört dolgu kelimeye ek olarak dört yeni kelime deneme bölümünde kullanılmış ve sonuçları analize dahil edilmemiştir.

\section{Araştırma Deseni}

Çalışmanın deney deseni 4 (liste türü: eşit semantik ilişki-karışık liste, eşit semantik ilişki-tekli liste, eşit semantik ilişsi-karışık liste veya eşit semantik ilişki-tekli liste) x 2 (kelime grubu: uyarılmışlığı yüksek negatif kelimeler ve nötr kelimeler) karışık deney desenidir.

Çalışmada semantik ilişkisellik ve sunum şeklinin etkisine bakmak üzere ise iki ayrı deney deseni oluşturulmuştur. Sunum şeklinin tanıma doğruluğu üzerindeki etkisine bakmak için oluşturulan deney deseni 2 (sunum şekli: karışık veya tekli liste) x 2 (kelime grubu: uyarılmışlığı yüksek negatif kelimeler ve nötr kelimeler) karışık deney desenidir. Semantik ilişkiselliğin tepki yanlılı̆ğ üzerindeki etkisine bakmak için oluşturulan deney deseni ise 2 (semantik ilişkisellik: eşit veya değil) x 2 (duygu: uyarılmışlığı yüksek negatif kelimeler ve nötr kelimeler) karışık deney desenidir. Sunum şeklinin etkisini 
test etmek üzere 1. ve 4. liste ile 2. ve 3. liste karşılaştırılmıştır. Semantik ilişkiselliğin etkisini test etmek üzere ise 1 . ve 2. liste ile 3. ve 4. liste karşılaştırılmıştır.

Birinci deneyde olduğu gibi bu deneyde de sinyal tespit analizi (Macmillan ve Creelman, 2005) kullanılarak katılımcıların isabet ve yanlış alarm oranları, duyarlılık (AUC) ve tepki yanlılığ $1(c)$ parametreleri hesaplanmış ve bu değerler bağımlı değişkenler olarak ayrı ayrı analize sokulmuştur.

\section{Veri Analizi}

Deneyden elde edilen veriler IBM SPSS23 paket programı kullanılarak analiz edilmiştir. Yürütülen karışık desenler için ANOVA analizinin tüm varsayımları karşılanmıştır. Anlamlı etkileşimler için yapılan izleme testlerinde Bonferroni düzeltmesi uygulanmış ve sonuçlar düzeltilmiş şekilde raporlanmıştır. Verinin tanımlayıcı değerleri aşağıda, Tablo 2'de verilmiştir.

Tablo 2. Farklı Sunum Listelerine Ait Ortalama ve Standart Sapma Değerleri

\begin{tabular}{|c|c|c|c|}
\hline & & Nötr Kelimeler & Uyarılmışlığı Yüksek Negatif Kelimeler \\
\hline & & $\bar{X}$ & $\bar{X}$ \\
\hline \multirow[t]{4}{*}{ İsabet Oranları } & EDT & $.70(.18)$ & $.75(.12)$ \\
\hline & ET & $.65(.23)$ & $.72(.12)$ \\
\hline & EK & $.61(.15)$ & $.70(.16)$ \\
\hline & EDK & $.66(.13)$ & $.80(.10)$ \\
\hline \multirow{4}{*}{$\begin{array}{l}\text { Yanlış Alarm } \\
\text { Oranları }\end{array}$} & EDT & $.16(.13)$ & $.38(.19)$ \\
\hline & ET & $.14(.09)$ & $.39(.16)$ \\
\hline & EK & $.11(.07)$ & $.35(.14)$ \\
\hline & EDK & $.13(.08)$ & $.38(.15)$ \\
\hline \multirow[t]{4}{*}{ Duyarlılık Puanları } & EDT & $.81(.11)$ & $.75(.12)$ \\
\hline & ET & $.81(.13)$ & $.76(.10)$ \\
\hline & EK & $.81(.09)$ & $.73(.11)$ \\
\hline & EDK & $.83(.09)$ & $.79(.10)$ \\
\hline \multirow[t]{4}{*}{ Yanlılık Puanları } & EDT & $.29(.47)$ & $-.18(.40)$ \\
\hline & ET & $.39(.41)$ & $-.10(.48)$ \\
\hline & EK & $.55(.34)$ & $-.09(.35)$ \\
\hline & EDK & $.37(.33)$ & $-.3(.31)$ \\
\hline
\end{tabular}

Not. $\bar{X}$, ortalamayı, parantez içinde verilen değerler ise standart sapmayı belirtmektedir. EDT: Eşit Semantik ilişkili Değil-Tekli liste. ET: Eşit semantik iliş̧ili-Tekli liste. EDK: Eşit semantik ilişkili Değil-Karışık liste. EK: Eşit semantik ilişkili-Karışık liste. 


\section{BULGULAR}

\section{İsabet ve Yanlış Alarm Oranları}

Karışı desenler için ANOVA analizinin sonuçlarına göre kelime grubunun hem isabet $\left(F(1,76)=20.20, p<.001, \eta_{\mathrm{p}}^{2}=.21\right)$ hem de yanlış alarm oranları $(F(1,76)=$ 199.96, $\left.p<.001, \eta_{\mathrm{p}}^{2}=.73\right)$ üzerinde anlamlı etkisi bulunmuştur. Öte yandan sunum şeklinin isabet $(F(1,78)=1.16, p>.05)$ veya yanlış alarm $(F(1,78)=.20, p>.05)$ oranları üzerinde anlamlı etkisi bulunmamıştır. Benzer şekilde semantik ilişkiselliğin de isabet $(F(1,78)=.02, p>.05)$ veya yanlış alarm $(F(1,78)=.21, p>.05)$ oranları üzerinde anlamlı bir etkisi görülmemiştir. Ayrıca isabet $(F(3,76)=.59, p>.05)$ veya yanlış alarm oranlarının $(F(3,76)=.31, p>.05)$ dört liste arasında farklılaşmadığı görülmüştür.

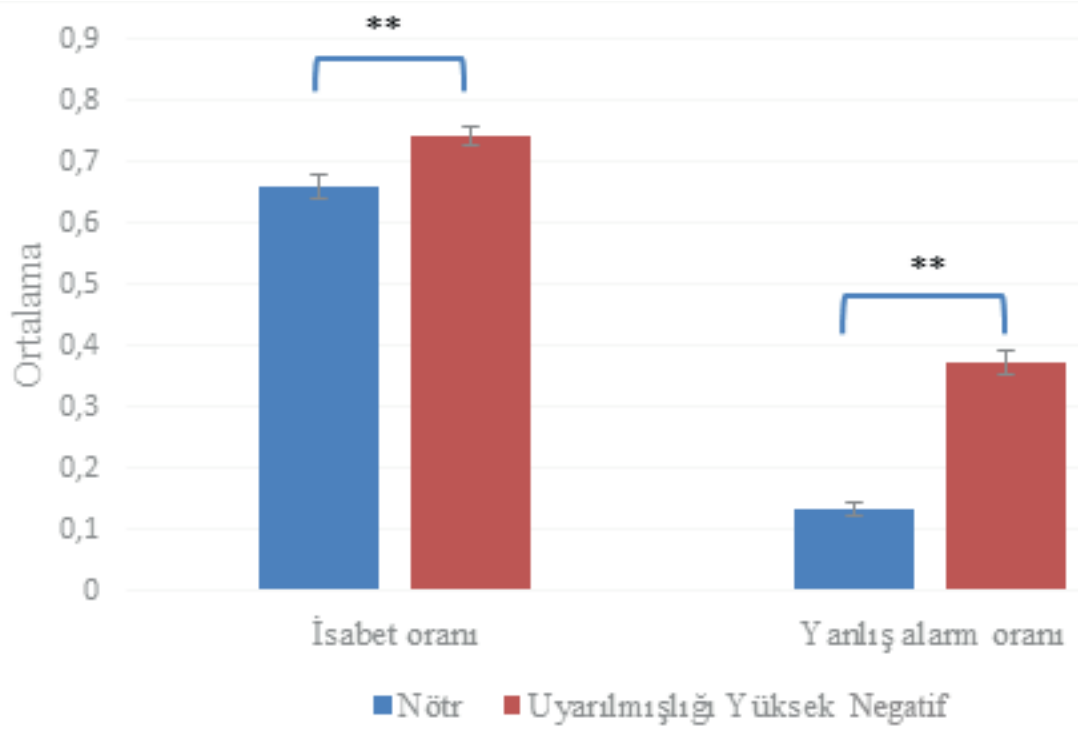

Şekil 3. Kelime Gruplarına (Nötr ve Uyarılmışlığı Yüksek Negatif) Göre İsabet ve Yanlış Alarm Oranları

Birinci deneyde olduğu gibi, sonuçlar isabet ve yanlış alarm oranlarının nötr kelimelere kıyasla uyarılmışlığı yüksek negatif kelimeler için anlamlı şekilde daha yüksek olduğunu göstermiştir. Bellek performansı hem isabet hem de yanlış alarm oranları kullanılarak hesaplanan duyarlılık $(A U C)$ ve yanlılık $(c)$ değerleri temelinde analiz edilmiştir. Tanıma performansını doğruluk ve yanlılık ölçümlerini ayrı ayrı göz önünde bulundurarak test etmek üzere sinyal tespit analizleri gerçekleştirilmiştir. 


\section{Sinyal Tespit Analizleri ve ROC Ĕgrileri}

ROC eğrilerine göre (Bkz. Şekil 4), birinci deneyde olduğu gibi, nötr kelimelere ait eğrinin sol üst köşeye daha yakın olduğu görülmektedir ve bu da katılımcıların uyarılmışlığı yüksek negatif kelimelere kıyasla nötr kelimeler için daha fazla tanıma duyarlılığ1 gösterdiklerine işaret etmektedir. Bununla birlikte, uyarılmışlığı yüksek negatif kelimelere ait eğrinin daha içeriden başladığı görülmektedir. Aynı güven aralığı için hem isabet hem de yanlış alarm oranları, nötr kelimelere kıyasla daha yüksektir ve bu da bu kelimelere karşı liberal tepki yanlılığı gösterilmiş olduğuna işaret etmektedir. ROC eğrilerinin gözlenmesiyle yapılan bu çıkarımları istatistiksel olarak desteklemek amacıyla, her bir katılımcı için duyarlılık $(A U C)$ ve yanlılık $(c)$ parametreleri hesaplanmış ve bu değerler bağımlı değişkenler olarak analize dahil edilmiştir. Böylelikle tanıma doğruluğu ve tepki yanlılığg hem isabet hem de yanlış alarm değerleri göz önünde bulundurularak hesaplanmıştır.

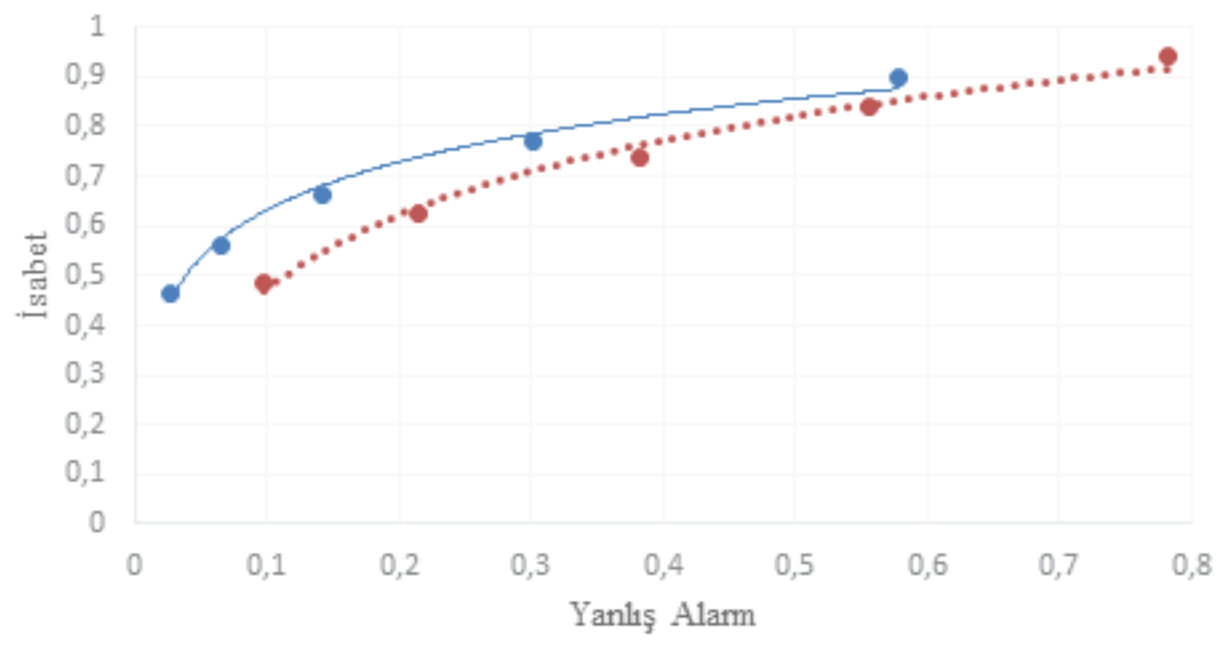

-Nötr •Uyarilmışlığı yülksek negatif

Şekil 4. Kelime Gruplarının (Nötr ve Uyarılmışlığı Yüksek Negatif) ROC Eğrileri

Tanıma Doğruluğu/Duyarlıık (AUC). Karışık desenler için ANOVA analizi sonuçları kelime grubunun tanıma doğruluğunu anlamlı şekilde etkilediğini $(F(1,76)=$ $34.94, p<.001, \eta_{\mathrm{p}}^{2}=.32$ ) ve nötr kelimelerin (Ort. $\left.=.82, S S=.01\right)$, uyarılmışlığı yüksek negatif kelimelerden (Ort. $=.76, S S=.01)$ anlamlı şekilde daha doğru tanındığını göstermiştir. Sunum şeklinin $(F(1,78)=.07, p>.05)$ veya semantik ilişkiselliğin $(F(1$, 
$78)=.32, p>.05)$ tanıma doğruluğu üzerinde anlamlı bir etkisi bulunmamıştır. Ayrıca, tanıma doğruluğunun dört sunum listesi arasında farklılaşmadığı görülmüsştür $(F(3,76)$ $=.64, p>.05)$.

Tepki Yanlılığı (c). Karışık desenler için ANOVA analizi sonuçları kelime grubunun tepki yanlılığını anlamlı şekilde etkilediğini $\left(F(1,76)=133.32, p<.001, \eta_{\mathrm{p}}{ }^{2}=.64\right)$ göstermiştir. Katılımcılar uyarılmışlığ yüksek negatif kelimelere (Ort. $=-.17, S S=.04)$ nötr kelimelerden (Ort. $=.40, S S=.04)$ daha fazla "eski" deme yanlıllğı göstermişlerdir. Sunum şeklinin $(F(1,78)=2.88, p>.05)$ veya semantik ilişkiselliğin $(F(1,78)=.001, p$ $>$.05) tepki yanlılı̆̆ üzerinde anlamlı bir etkisi bulunmamıştır. Bununla birlikte tepki yanlılığının dört sunum listesi arasında da farklılaşmadığı bulunmuştur $(F(3,76)=.97$, $p>.05)$.

\section{Kelimelerin Ayrık Duygu Kategorilerine Göre Değerlendirilmesi}

Çalışmada kullanılan nötr ve duygusal kelimeler yukarıda açıklandığı gibi Duygunun Döngüsel Modeli (Russell, 1980) baz alınarak uyarılmışlık ve değerlik boyutları üzerinden seçilmiştir. Bununla birlikte mevcut çalışmada kullanılan kelimelerin ayrık duygular temelinde nasıl gruplandıklarına da bakılmıştır. Söz konusu kelimelerin üzüntü, korku, mutluluk, öfke ve tiksinti temel duyguları bakımından sınıflandırılmaları yapılmaya çalışılmıştır. Bu amaçla kullanılan 120 kelime için temel duygular (üzüntü, korku, tiksinti, öfke, mutluluk) ayırıcı değişkenler olarak ele alınmış ve iki gruplu Diskriminant Fonksiyon Analizi yapılmıştır. Analizden elde edilen örtük yapıyla üzüntü, korku, tiksinti ve öfkenin pozitif; mutluluğun negatif korelasyona sahip olduğu bulunmuştur. Gruplar arası farklılıkların istatistiksel olarak anlamlı bir yüzdesini açıklayan diskriminant yüzdesi elde edilmiştir (Wilk's Lambda $=.212, \chi^{2}(N=120)=179.30, p<$ $.001, \mathrm{R}_{\mathrm{c}}^{2}=.788$ ). Dışlama (Leave-one-out) yöntemi kullanılarak yapılan diskriminant analizinde kelimelerin \%95'i doğru şekilde sınıflandırılmıştır (Press' $\mathrm{Q}=97.2, p<.05$ ). $\mathrm{Bu}$ analiz, duygusal kelimelerin negatif duygu kategorilerine, nötr kelimelerin ise pozitif duygu kategorisine yakın olduğunu göstermiştir.

\section{TARTIŞMA}

Sonuçlar isabet, yanlış alarm, doğruluk veya yanlılık değerlerinin sunum şekline veya semantik ilişkiselliğe göre farklılaşmadığını göstermiştir. Bununla birlikte, birinci deneyle tutarlı şekilde tanıma doğruluğunun uyarılmışlığı yüksek negatif kelimelere k1yasla nötr kelimeler için daha yüksek olduğu ve uyarılmışlığı yüksek negatif kelimeler 
için liberal tepki yanlılı̆̆1 gösterildiği bulunmuştur. Ayrıca yine birinci deneyde olduğu

gibi uyarılmışlığı yüksek negatif kelimelerin nötr kelimelere kıyasla daha fazla isabet ve yanlış alarm oranlarına sahip olduğu görülmüştür. Sonuç olarak bu deneyde tanıma doğruluğu üzerinde etkili olması beklenen sunum şeklinin $\left(H_{3}\right)$ ve tepki yanlılığı üzerinde etkili olması beklenen semantik ilişkiselliğin $\left(H_{4}\right)$ anlamlı bir etkisi bulunmamıştır.

Özetle, analiz sonuçları sunum şeklinin ve semantik ilişkiselliğin tanıma performans1 üzerinde anlamlı bir etkiye sahip olmadığını göstermiştir. Birinci deneyle tutarlı olarak, bu deneyin her koşulunda nötr kelimelerin uyarılmışlı̆̆ yükssek negatif kelimelerden daha iyi tanındıkları ve uyarılmışlığı yüksek negatif kelimelere yönelik olarak liberal tepki yanlılığı gösterildiği bulunmuştur.

\section{GENEL TARTIŞMA}

Bu çalışmada duygusal ve nötr uyaran belleği sağlamlaşma ve kodlama süreçleri temelinde karşılaştırılmıştır. Tepki yanlılığını göz önünde bulundurmak amacıyla yapılan sinyal tespit analizi sonucunda ne sağlamlaşma aşamasında etkili olması beklenen zaman aralığının ve karıştırıcı görevin ne de kodlama aşamasında etkili olması beklenen semantik ilişkiselliğin ve sunum şeklinin tanıma performansı üzerinde anlamlı bir etkisi bulunmuştur. Bununla birlikte her iki deneyde de tutarlı şekilde nötr kelimelerin uyarılmışlığı yüksek negatif kelimelerden daha iyi tanındığ 1 ve uyarılmışlığg yüksek negatif kelimelere yönelik liberal tepki yanlılığında bulunulduğu görülmüştür.

Çalışmanın ilk deneyinde, duygusal uyaranların kodlama aşamasından sonra avantajlı hale geldiğini vurgulayan sağlamlaşma çalışmaları göz önünde bulundurulmuştur. Bu şekilde farklı zaman aralıklarının ve sağlamlaşma sürecinde karıştırıcı görevin verilmesinin etkileri incelenmiştir. Sonuçlar zaman aralığının veya karıştırıcı görev verilmesinin katılımcıların tanıma belleği performansı üzerinde anlamlı bir etkiye sahip olmadığını göstermiştir. Bu bulgu kodlamadan sonra geçen sürenin (Kleinsmith ve Kaplan, 1963; McGaugh, 2004; Park, 2005) ve bu süreçteki karıştırıcılara yönelik direncin (Cocenas-Silva ve ark., 2013) duygusal uyaranlara bellek avantajı sağladığını savunan önceki çalışmaları desteklememektedir. Sağlamlaşma aşaması test edilirken Nielson ve Powless'ın (2007) sağlamlaşma etkisinin 30. dakikada ortaya çıktığını savunan çalışmas1 ile Kleinsmith ve Kaplan'ın (1963) duygusal uyaranlar için kritik zamanın 20. dakika olduğunu belirttiği çalışması temel alınmıştır. Mather (2007) söz konusu bu çalışmalarda zaman aralığının duygusal uyaranlara sağladığı bellek avantajının aslında öncelik ve 
sonralık etkilerinden kaynaklanabileceğini belirtmektedir. Öncelik ve sonralık etkilerinin bu çalışmada kontrol edilmiş olması zaman aralığının beklenen etkisinin görülmemesine neden olmuş olabilir.

Zaman aralığının etkisinin görülmemesinin bir diğer nedeni de kullanılan sürelerin yeterince uzun olmaması ve sağlamlaşma sürecindeki önemi son yıllarda sıklıkla vurgulanan uykunun (Maquet, 2001; Stickgold, 2005) bu zaman aralıklarına dahil olmamas1 olabilir. Uykunun öğrenilen bilginin bellekte sağlamlaşması için oldukça önemli olduğu ve karıştırıcıların etkisini azalttığı savunulmaktadır (Rasch ve Born, 2013). Bununla birlikte uyku, duygusal ve nötr bilginin bellekte kalıcılığını farklı şekillerde etkileyebilmektedir. Örneğin, uykunun duygusal bilgiye bellekte dört yıl sonrası için bile süren kalıcılık sağlarken nötr bilgi için böyle bir avantaj sağlamadığı bulunmuştur (Wagner, Hallschmid, Rasch ve Born, 2006). Sharot ve Yonelinas'ın (2008) bir günlük sağlamlaşma sürecinde duygusal uyaranlar için bellek avantajının ortaya çıktığını gösterdikleri çalışmaları da uykunun bu süreçte önemli olabileceği görüşünü desteklemektedir. Öte yandan, Wang (2014) duygusal resimlere yönelik tanıma belleğini test ettiği çalışmasında 24 saatte duygusal ve nötr uyaran belleği arasında farklılaşma gerçekleşmediğini bulmuştur. Ek olarak, Mather, Gorlick ve Nesmith (2009) iki gün sonunda bile duygusal uyaranların sağlamlaşma avantajı göstermediğini ortaya koymuşlardır. Dolayısıyla sağlamlaşma aşamasında daha uzun zaman aralıklarının ve uykunun önemi vurgulansa da yapılan çalışmalar çelişkili sonuçlar sunmaktadır. Sağlamlaşma, kısa zaman aralıklarını kapsayan sinaptik sağlamlaşma ve günler, yıllar gibi daha uzun süreçleri kapsayan sistemsel sağlamlaşma olarak ikiye ayrılmaktadır (Dudai, 2004). Dolayısıyla, duygunun sağlamlaşma sürecinde sahip olması beklenen avantajın tutarlı şekilde görülebilmesi için sistemsel sağlamlaşmanın, diğer bir ifadeyle uyku süreçlerini içeren haftalar ve yılları kapsayan daha uzun zaman aralıklarının gerekli olduğu düşünülebilir.

Araştırmanın ikinci deneyi kodlama aşamasında etkili olabileceği düşünülen değişkenlerin tanıma performansı üzerinde anlamlı bir etkiye sahip olmadığını göstermiştir. Kodlama sırasında duygusal ve nötr uyaranların karışık şekilde sunulması sonucunda taşıma etkisinin (Schmidt ve Schmidt, 2016) veya duygusal bulaşma etkisinin (Hatfield ve ark., 1992) ortaya çıkmış olması ihtimali test edilmiştir. Sonuçlar, duygusal ve nötr uyaranların tekli veya karışık şekilde sunulmasının tanıma doğruluğunu etkilemediğini göstermiştir. Benzer şekilde, kodlama aşamasında etkili olabileceği savunulan semantik ilişkiselliğin duygusal uyaranlara yönelik liberal tepki yanlılı̆̆ üzerinde anlamlı bir et- 
kisi bulunmamıştır. Bununla birlikte, deney 2'de de birinci deneyde olduğu gibi nötr kelimelerin uyarılmışlığı yüksek negatif kelimelere kıyasla daha iyi tanındığı ve uyarılmışlığ1 yüksek negatif kelimelere yönelik liberal tepki yanlılığ1 gösterildiği görülmüştür.

Söz konusu bulgular, bağlantılı alan yazındaki teorik yaklaşımlar, yorumlar ve bulgular açısından tartışılacak olursa, ilk olarak bu çalışma kullanılan analiz yöntemi bakımından önceki birçok çalışmadan farklılaşmaktadır. Çalışmanın her iki deneyinde de sinyal tespit analizi kullanılmıştır. Sinyal tespit analizi tanıma doğruluğu ve tepki yanlılığının ayrı ayrı değerlendirilmesine olanak sağlamaktadır. Dougal ve Rotello (2007) sinyal tespit analizi kullanarak ele aldıkları çalışmalarında duygusal uyaranlar için tanıma doğruluğunun daha iyi olmadığını, daha ziyade duyguya yönelik olarak tepki yanlılığ 1 yapıldığını göstermişlerdir. Bu çalışmada da duygusal uyaranların sahip olduğu öne sürülen bellek avantajının görülmemesinin ve genel olarak daha kötü tanınmalarının sinyal tespit analizi yönteminin kullanılmasıyla ilişkili olabileceği düşünülmüştür. Bununla birlikte, mevcut çalışmada duygusal uyaranlara yönelik yanlış alarmların fazla olması ve bunun neticesinde de bu uyaranlar için tanıma doğruluğunun azalıp liberal tepki yanlılığının artması duygunun işlevine ilişkin yeni açıklamalara işaret etmektedir. Duygunun tanıma doğruluğundan ziyade liberal tepki yanlılığını artırması olası önemli olayların ıskalanması (miss) riskini azaltmaktadır. Önemli bir olayı 1skalamak, bu olayı yanlış hatırlamaktan daha yüksek maliyete sebep olabileceğinden duygunun bellekteki işlevinin tanıma doğruluğunu değil liberal tepki yanlılığını artırmak olduğu söylenebilir (Lynn ve Barrett, 2014).

Bu çalışmada duygusal ve nötr kelimelerin semantik ilişkisellik değerleri dengelenerek kategori etkisi azaltılmaya çalışılmıştır. Öte yandan, White ve arkadaşları (2014) duygusal ve nötr uyaranların anlamsal ilişkisellik açısından eşitlense bile kategori etkisinin ortaya çıkabileceğini savunmuşlardır. Duygusal uyaranların bir duygu kategorisini temsil ederken (örn., tiksinme, korku, mutluluk vb.), nötr olmanın bir kategoriyi temsil etmediği görüşünü ileri sürmüşlerdir. White ve arkadaşları (2014) çalışmalarında negatif kelimelere karşı gösterilen tanıma yanlılığının bu uyaranların çalışma listesinde belirgin bir kategoriyi oluşturmaları sonucunda ortaya çıktığını, uyarılmışlık ve değerliğin ana etki olmadığını savunmuşlardır. Bununla birlikte negatif ve kategorik nötr kelimelere gösterilen tepki yanlılığı örüntüsü benzer olsa da kategori üyeliği etkisinin negatif kelimeler için daha güçlü olduğunu ortaya koymuşlardır. 
$\mathrm{Bu}$ çalışmada duygusal uyaran belleğinde etkili olabilecek diğer birçok değişken kontrol edilmeye çalışılmıştır. Birincisi, katılımcıların kodlama sırasında duygusal ve nötr uyaranlara yönelik farklı tanıma stratejileri kullanması engellenmeye çalışılmıştır. Tesadüfi kodlama prosedürleri katılımcıların duygusal uyaranlara yönelik tanıma stratejileri kullanmalarını veya dikkatin tek bir uyaran tipine yönelmesini engelleyebilmektedir (Anderson, Wais ve Gabrieli, 2006; Schmidt ve Schmidt, 2016). Bu nedenle tesadüfi kodlama yöntemi kullanılmış ve katılımcılar sonradan gelecek bellek testi konusunda bilgilendirilmemiştir. İkinci olarak duygusal ve nötr kelimeler negatif uyarılmışlık d1Şında kalan özellikler bakımından dengelenmeye çalışılmıştır. Bu amaçla duygusal ve nötr kelimelerin kullanım sıklığı ve uzunluğu kontrol edilmiştir. Sonuç olarak, elde edilen bulgular sağlamlaşma ve kodlama aşamasında etkili olması beklenen değişkenlerin anlamlı bir etkiye sahip olmadıklarını göstermiştir. Öte yandan her iki deneyde duygunun tanıma performansı üzerinde etkili olduğu gösterilmiştir.

Ele alınan iki deney, sağlamlaşma ve kodlama aşamalarının koşullarına göre değişmeksizin duygunun aynı şekilde etkili olduğunu göstermiştir. Farklı manipülasyonlara rağmen her iki deneyde de benzer sonuçlar alınması bellek performansındaki farklılaşmanın tanıma testi sırasında ortaya çıkmış olabileceğini düşündürmektedir. Bu araştırmada sağlamlaşma ve kodlama aşamasına odaklanılırken geri getirmenin gerçekleştiği tanıma testi aşaması üzerinde durulmamıştır. Farklı manipülasyonlara rağmen tüm katılımcılar tanıma testi sırasında aynı kelimeleri eski veya yeni olarak değerlendirmişlerdir. Tanıma testi sırasında katılımcıların beyin aktivasyonlarının ölçümlendiği bir çalışma, katılımcıların yeni nötr kelimelere kıyasla yeni negatif kelimelere karşı daha fazla nöral aktivasyon gösterdiğini ve daha fazla yanlış alarm verdiklerini göstermiştir (Maratos, Allan ve Rugg, 2000). Benzer şekilde, semantik ilişkisellik gibi organizasyonla alakalı süreçlerin yalnızca kodlama aşamasında değil geri getirme aşamasında da etkili olabileceği öne sürülmektedir (Brainerd, Stein, Silveira, Rohenkohl ve Reyna, 2008; Buchanan ve ark., 2006; Hunt ve McDaniel, 1993; Tulving ve Pearlstone, 1966). Buradan hareketle her iki deneyde de uygulanan manipülasyonların anlamlı bir etkisi yokken duygunun tutarlı şekilde etkili olmasının tanıma testi sırasında gerçekleşen süreçlerle ilişkili olabileceği düşünülmektedir. Bu iddianın ileriki çalışmalar tarafından test edilmesi önerilmektedir.

Mevcut çalışma kullanılan kısa zaman aralıkları, uyaranların sahip olduğu birtakım özellikler ve tanıma testi sırasında ortaya çıkabilecek diğer bilişsel etmenler bakımından 
bazı sınırlılıklar içermektedir. Organizasyonel süreçlerin etkilerine vurgu yapan birçok çalışmada duygunun kategori etkisi oluşturmasıyla tanıma testlerinde liberal tepki yanlılığını artırdığı savunulmaktadır (Maratos ve ark., 2000). Mevcut araştırmada kullanılan duygusal ve nötr kelimeler uyarılmışlık ve değerlik boyutlarına göre seçilmiştir. Bununla birlikte bu kelimeler ayrik duygu kategorileri (Ekman, 1999) temelinde de birbirlerinden ayrışabilmektedir. Karaaslan, Siakir-Oglou ve Kapucu (2019) tarafından gerçekleştirilen bir çalışma, öfke ve üzüntü duygularının isabet oranı ve tanıma yanlılığını farklı şekillerde etkilediğini göstermiştir. Buradan hareketle mevcut çalışmada kullanılan kelimelerin ayrık duygular temelinde nasıl gruplandıklarına ikinci deneyin analizleri sırasında bakılmıştır. Sonuç olarak, bu çalışmada kullanılan duygusal kelimelerin negatif duygu kategorilerine, nötr kelimelerin ise pozitif duygu kategorisine yakın olduğu görülmüştür. Negatif kategorik duygular bellek ile ilişkileri bakımından kendi içlerinde farklılaşabilmektedir. Örneğin, aynı uyarılmışlık ve değerlik düzeyine sahip olsalar da tiksinti içerikli uyaranlar korku içerikli uyaranlardan daha iyi hatırlanabilmektedir (Chapman, Johannes, Poppenk, Moscovitch ve Anderson, 2013). Dolayısıyla bu çalışmada kullanılan duygusal kelimelerin farklı kategorik duyguları temsil etmesi ve kullanılan nötr kelimelerin nispeten pozitif duygu kategorisine yakın olması ulaşılan sonuçları etkilemiş olabilir.

Mevcut çalışma, duygusal tanıma belleğini daha kapsamlı şekilde ele alması ve duygusal bilginin daha iyi hatırlandığı yaygın görüşüne eleştiri getirmesi bakımından öneme sahiptir. Tepki yanlılığını göz önünde bulundurarak duygusal tanıma performansını test edecek ileriki çalışmalarda söz konusu sınırlılıklara dikkat edilmesi ve özellikle tanıma testi aşaması üzerinde durulması önerilmektedir. Sonuç olarak bu çalışma, duygusal belleğin geniş bir çerçevede değerlendirilmesi ve işlevlerinin göz önünde bulundurulması gerektiğine işaret etmesi bakımından alan yazına önemli bir katkı sağlayacaktır.

Hakem Değerlendirmesi: Dış bağımsız.

Çıkar Çatışması: Yazarlar çıkar çatışması bildirmemiştir.

Finansal Destek: Yazarlar bu çalışma için finansal destek almadığını beyan etmiştir.

Peer-review: Externally peer-reviewed.

Conflict of Interest: The authors have no conflict of interest to declare.

Grant Support: The authors declared that this study has received no financial support. 


\section{Kaynakça/References}

Anderson, A. K., Wais, P. E. ve Gabrieli, J. D. (2006). Emotion enhances remembrance of neutral events past. Proceedings of the National Academy of Sciences, 103(5), 1599-1604.

Been, M., Jans, B. ve De Weerd, P. (2011). Time-limited consolidation and task interference: No direct link. Journal of Neuroscience, 31(42), 14944-14951.

Brainerd, C. J., Stein, L. M., Silveira, R. A., Rohenkohl, G. ve Reyna, V. F. (2008). How does negative emotion cause false memories?. Psychological Science, 19(9), 919-925.

Buchanan, T. W., Etzel, J. A., Adolphs, R. ve Tranel, D. (2006). The influence of autonomic arousal and semantic relatedness on memory for emotional words. International Journal of Psychophysiology, 61(1), 26-33.

Cahill, L. ve McGaugh, J. L. (1998). Mechanisms of emotional arousal and lasting declarative memory. Trends in Neurosciences, 21(7), 294-299.

Chapman, H. A., Johannes, K., Poppenk, J. L., Moscovitch, M. ve Anderson, A. K. 2013). Evidence for the differential salience of disgust and fear in episodic memory. Journal of Experimental Psychology: General, 142(4), 1100-1112.

Cocenas-Silva, R., Bueno, J. L. O. ve Droit-Volet, S. (2013). Emotion and long-term memory for duration: Resistance against interference. Behavioural Processes, 97, 6-10.

DeSchepper, B. ve Treisman, A. (1996). Visual memory for novel shapes: Implicit coding without attention. Journal of Experimental Psychology: Learning, Memory, and Cognition, 22(1), 27-47.

Dougal, S. ve Rotello, C. M. (2007). "Remembering" emotional words is based on response bias, not recollection. Psychonomic Bulletin \& Review, 14(3), 423-429.

Dudai, Y. (1996). Consolidation: Fragility on the road to the engram. Neuron, 17(3), 367-370.

Dudai, Y. (2004). The neurobiology of consolidations, or, how stable is the engram?. Annual Review of Psychology, 55, 51-86.

Ekman, P. (1999). Basic emotions. Handbook of Cognition and Emotion, 98(45-60), 45-61.

Göz, İ. (2003). Yazılı Türkçenin kelime sıklı̆̆ı sözlüğü. Türk Dil Kurumu: Ankara.

Hatfield, E., Cacioppo, J. T. ve Rapson, R. L. (1992). Primitive emotional contagion. Review Of Personality and Social Psychology, 14, 151-177.

Hunt, R. R. ve McDaniel, M. A. (1993). The enigma of organization and distinctiveness. Journal of Memory and Language, 32(4), 421-445.

Kapucu, A., Kılıç, A., Özkılıç, Y. ve Sarıbaz, B. (2018). Turkish emotional word norms for arousal, valence, and discrete emotion categories. Psychological Reports, 0033294118814722.

Kapucu, A., Rotello, C. M., Ready, R. E. ve Seidl, K. N. (2008). Response bias in" remembering" emotional stimuli: A new perspective on age differences. Journal of Experimental Psychology: Learning, Memory, and Cognition, 34(3), 703-711.

Karaaslan, A., Siakir-Oglou, N. ve Kapucu, A. (2019). Duygusal uyarılmışlığın tanıma belleği üzerindeki ketleyici etkisi: Nesne içi ve Nesneler arası bağlantıların karşılaştırılması. Psikoloji Çalı̧̧maları, 39(2), 1-2.

Kleinsmith, L. J. ve Kaplan, S. (1963). Paired-associate learning as a function of arousal and interpolated interval. Journal of Experimental Psychology, 65(2), 190-193.

Lechner, H. A., Squire, L. R. ve Byrne, J. H. (1999). 100 years of consolidation-remembering Müller and Pilzecker. Learning \& Memory, 6(2), 77-87.

Lynn, S. K., ve Barrett, L. F. (2014). "Utilizing” signal detection theory. Psychological Science, 25(9), 1663-1673.

Macmillan, N. A. ve Creelman, C. D. (2005). Detection theory: A user's guide (2. bask1). Mahwah, NJ, US: Lawrence Erlbaum Associates Publishers. 
Maquet, P. (2001). The role of sleep in learning and memory. Science, 294(5544), 1048-1052.

Maratos, E. J., Allan, K. ve Rugg, M. D. (2000). Recognition memory for emotionally negative and neutral words: An ERP study. Neuropsychologia, 38(11), 1452- 1465.

Mather, M. (2007). Emotional arousal and memory binding: An object-based framework. Perspectives on Psychological Science, 2(1), 33-52.

Mather, M., Gorlick M. ve Nesmith, K. (2009). The limits of arousal's memory impairing effects on nearby information. The American Journal of Psychology, 122(3), 349-369.

Mathôt, S., Schreij, D. ve Theeuwes, J. (2012). OpenSesame: An open-source, graphical experiment builder for the social sciences. Behavior Research Methods, 44(2), 314-324.

McGaugh, J. L. (2004). The amygdala modulates the consolidation of memories of emotionally arousing experiences. Annual Review of Neuroscience, 27, 1-28.

McGaugh, J. L. (2018). Emotional arousal regulation of memory consolidation. Current Opinion in Behavioral Sciences, 19, 55-60.

Nielson, K. A. ve Powless, M. (2007). Positive and negative sources of emotional arousal enhance longterm word-list retention when induced as long as $30 \mathrm{~min}$ after learning. Neurobiology of Learning and Memory, 88(1), 40-47.

Park, J. (2005). Effect of arousal and retention delay on memory: A meta analysis. Psychological Reports, 97(2), 339-355.

Posner, J., Russell, J. A. ve Peterson, B. S. (2005). The circumplex model of affect: An integrative approach to affective neuroscience, cognitive development, and psychopathology. Development and Psychopathology, 17(3), 715-734.

Rasch, B. ve Born, J. (2013). About sleep's role in memory. Physiological Reviews, 93(2), 681-766.

Robertson, E. M. (2012). New insights in human memory interference and consolidation. Current Biology, 22(2), 66-71.

Russell, J. A. (1980). A circumplex model of affect. Journal of Personality and Social Psychology, 39(6), 1161-1178.

Schmidt, S. R. ve Schmidt, C. R. (2016). The emotional carryover effect in memory for words. Memory, 24(7), 916-938.

Sharot, T. ve Yonelinas, A. P. (2008). Differential time-dependent effects of emotion on recollective experience and memory for contextual information. Cognition, 106(1), 538-547.

Snodgrass, J. G. ve Corwin, J. (1988). Pragmatics of measuring recognition memory: Applications to dementia and amnesia. Journal of Experimental Psychology: General, 117(1), 34-50. doi: 10.1037/0096-3445.117.1.34

Stickgold, R. (2005). Sleep-dependent memory consolidation. Nature, 437(7063), 1272-1278.

Talmi, D. (2013). Enhanced emotional memory: Cognitive and neural mechanisms. Current Directions in Psychological Science, 22(6), 430-436.

Talmi, D., Luk, B. T., McGarry, L. M. ve Moscovitch, M. (2007). The contribution of relatedness and distinctiveness to emotionally-enhanced memory. Journal of Memory and Language, 56(4), 555574.

Talmi, D. ve Moscovitch, M. (2004). Can semantic relatedness explain the enhancement of memory for emotional words?. Memory \& Cognition, 32(5), 742-751.

Talmi, D., Schimmack, U., Paterson, T. ve Moscovitch, M. (2007). The role of attention and relatedness in emotionally enhanced memory. Emotion, 7(1), 89-102.

Tulving, E. ve Pearlstone, Z. (1966). Availability versus accessibility of information in memory for words. Journal of Verbal Learning \& Behavior, 5, 381-391. 
Tyng, C. M., Amin, H. U., Saad, M. N. ve Malik, A. S. (2017). The influences of emotion on learning and memory. Frontiers in Psychology, 8, 14541476.

Wagner, U., Hallschmid, M., Rasch, B. ve Born, J. (2006). Brief sleep after learning keeps emotional memories alive for years. Biological Psychiatry, 60(7), 788-790.

Wang, B. (2014). Effect of time delay on recognition memory for pictures: The modulatory role of emotion. PLoS ONE, 9(6): e100238.

White, C. N., Kapucu, A., Bruno, D., Rotello, C. M. ve Ratcliff, R. (2014). Memory bias for negative emotional words in recognition memory is driven by effects of category membership. Cognition \& Emotion, 28(5), 867-880. 